\title{
Review \\ Multifaceted Chromatin Structure and Transcription Changes in Plant Stress Response
}

\author{
Jin-Hong Kim ${ }^{1,2}$ (D)
}

check for

updates

Citation: Kim, J.-H. Multifaceted Chromatin Structure and Transcription Changes in Plant Stress Response. Int. J. Mol. Sci. 2021, 22, 2013. https://doi.org/10.3390/ ijms22042013

Academic Editor: Markus Proft

Received: 29 January 2021

Accepted: 16 February 2021

Published: 18 February 2021

Publisher's Note: MDPI stays neutral with regard to jurisdictional claims in published maps and institutional affiliations.

Copyright: (C) 2021 by the author. Licensee MDPI, Basel, Switzerland. This article is an open access article distributed under the terms and conditions of the Creative Commons Attribution (CC BY) license (https:// creativecommons.org/licenses/by/ $4.0 /)$.
1 Advanced Radiation Technology Institute, Korea Atomic Energy Research Institute, 29 Geumgu-gil, Jeongeup-si, Jeollabuk-do 56212, Korea; jhongkim@kaeri.re.kr; Tel.: +82-63-570-3333

2 Department of Radiation Science and Technology, University of Science and Technology, 217 Gajeong-ro, Yuseong-gu, Daejeon 34113, Korea

\begin{abstract}
Sessile plants are exposed throughout their existence to environmental abiotic and biotic stress factors, such as cold, heat, salinity, drought, dehydration, submergence, waterlogging, and pathogen infection. Chromatin organization affects genome stability, and its dynamics are crucial in plant stress responses. Chromatin dynamics are epigenetically regulated and are required for stress-induced transcriptional regulation or reprogramming. Epigenetic regulators facilitate the phenotypic plasticity of development and the survival and reproduction of plants in unfavorable environments, and they are highly diversified, including histone and DNA modifiers, histone variants, chromatin remodelers, and regulatory non-coding RNAs. They contribute to chromatin modifications, remodeling and dynamics, and constitute a multilayered and multifaceted circuitry for sophisticated and robust epigenetic regulation of plant stress responses. However, this complicated epigenetic regulatory circuitry creates challenges for elucidating the common or differential roles of chromatin modifications for transcriptional regulation or reprogramming in different plant stress responses. Particularly, interacting chromatin modifications and heritable stress memories are difficult to identify in the aspect of chromatin-based epigenetic regulation of transcriptional reprogramming and memory. Therefore, this review discusses the recent updates from the three perspectives-stress specificity or dependence of transcriptional reprogramming, the interplay of chromatin modifications, and transcriptional stress memory in plants. This helps solidify our knowledge on chromatin-based transcriptional reprogramming for plant stress response and memory.
\end{abstract}

Keywords: chromatin; chromatin remodeling; histone modification; transcription; transcriptional reprogramming; plant stress response; DNA methylation

\section{Introduction}

The chromatin structure in eukaryotic cells contributes to genome stability but also displays dynamics to counter endogenous or exogenous stress factors, and neighboring chromatin structures may influence local nucleosome positions and gene expression [1-4]. Chromatin dynamics are epigenetically regulated by such things as histone variants, histone modifications, DNA (de-)methylation, nucleosome remodeling, and regulatory RNA, such as non-coding RNA (ncRNA), and are related to structural changes of nucleosomes or chromatin, which may affect genome-wide or locus-specific gene expression [5-7]. For example, the MEDIATOR OF PARAMUTATION1 (MOP1)-mediated RNA-directed DNA methylation (RdDM) activity regulates higher-order chromatin organization and genome-wide transcription in Zea mays [8]. The Arabidopsis thaliana SWITCH/SUCROSE NON-FERMENTABLE (SWI/SNF) family chromatin remodelers, BRAHMA (BRM) and SPLAYED (SYD) upregulate the expression of CUP-SHAPED COTYLEDON (CUC) genes to form and maintain boundary cells during embryogenesis [9]. Epigenetic modulators, modifiers, and mediators along with transcription factors and mediators concertedly coordinate nucleosome dynamics and gene expression, allowing alternative nucleosome configurations at transcription sites [10-13]. 
Plants have a distinctive three-dimensional spatial organization of chromatin, including similar but functionally different compartments, domains, and loop structures to those found in animals, likely as a result of the lack of topologically associated domains (TADs) or a CCCTC-binding factor (CTCF), which are required for transcriptional regulation in mammalian cells [14]. It is currently unclear as to why plants did not evolve these TADs or a CTCF, although they are equipped with a more sophisticated strategy for epigenetic regulation of gene expression at the nucleosome level involving diverse histone variants, post-translational histone modifications, and CG/CHG/CHH DNA methylation [14,15]. SWI/SNF chromatin remodelers affect the expression of underlying genes for various functions, including cell differentiation, organ development, flower morphogenesis, and phytohormone signaling during plant development by facilitating chromatin remodeling and dynamics [16]. H1 linker histones can also contribute to the transcriptional and epigenetic control of developmental and cellular transitions through fine-tuning of the spatial organization of euchromatin and heterochromatin [17]. Chromatin-based epigenetic regulation is flexible and dynamic to facilitate rapid adaptation to environmental changes; therefore, it can be crucial for dealing with environmental stress responses $[1,2,18,19]$.

As sessile organisms, plants are inevitably exposed to various environmental stress factors, including cold, heat, salinity, drought, dehydration, submergence, waterlogging, and pathogen infection, throughout their lifetimes. To counter these, they are able to develop elaborated structural changes in chromatin and coordinate alterations in histone modification and DNA methylation for the expression of stress-responsive genes [1,2]. Reactive oxygen species (ROS) and nitric oxide (NO), which are indicators of stress responses, are considered pivotal in mediating chromatin dynamics through redox-dependent histone and DNA modifications [3]. The causal relationship between dynamic changes of chromatin composition and organization and stress-induced transcriptional alterations is undetermined in many cases, but an increasing number of reports support a correlation between these changes in diverse plant stress responses [20,21]. For example, the acetylation of H3K9 and H3K14, mediated by the histone acetyltransferase GENERAL CONTROL NON-REPRESSED PROTEIN5 (GCN5), contributes to thermotolerance or salt tolerance by activating heat or salt stress-responsive genes, such as HEAT SHOCK TRANSCRIPTION FACTOR A3 (HSFA3), UV-HYPERSENSITIVE6 (UVH6), CTL1, PGX3, and MYB54 [22,23]. Additionally, the bivalent H3K4me3 and H3K27me3 marks associated with active genes in response to cold stress represent enhanced chromatin accessibility, which may facilitate the access of regulatory proteins required for gene expression [24]. Recently, it has been reported that the HIGH EXPRESSION OF OSMOTICALLY RESPONSIVE GENE15 (HOS15)-mediated chromatin modifications are required for the recruitment of C-REPEAT BINDING FACTOR (CBF) transcription factors to COLD RESPONSIVE (COR) gene promoters [25]. The association of differentially methylated regions (DMRs) with many differentially expressed genes (DEGs) in bok choy (Brassica rapa) and rice (Oryza sativa) under heat, drought, or salinity stress, reveals the interaction between DNA methylation and gene expression in plant abiotic stress responses [26,27].

Chromatin dynamics are also critical for stress signaling, adaptation, and memory in plants through stress-induced transcriptional reprogramming. The proteolytic and nonproteolytic roles of the ubiquitin-proteasome system are associated with the regulation and coordination of plant responses to environmental signals, particularly in relation to the E3 ligases, which function as regulators in the jasmonic acid (JA), salicylic acid (SA), ethylene, and abscisic acid (ABA) signaling pathways that coordinate responses to multiple environmental stresses $[28,29]$. In contrast, histone acetylation and methylation correlate with biotic or abiotic stress memory, such as systemic acquired resistance and heat and dehydration stress priming $[30,31]$. Various chromatin-based epigenetic regulatory mechanisms are becoming more relevant in relation to stress adaptation and somatic, intergenerational, and transgenerational stress memory [32,33]. Although previous reviews have analyzed chromatin remodeling and epigenetic regulation in plant stress responses $[1,2,13,18,21,31]$, 
there is a need to update the available information on chromatin-based regulation of stress-responsive transcription and stress adaptation and memory in plants.

\section{Chromatin Modification and Epigenetic Regulation in Plants}

Epigenetic regulators are remarkably diversified in plants, facilitating the phenotypic plasticity of plant development and the survival and reproduction in unfavorable environments (Figure 1) [2,34]. Interactions of such functions as histone modifications, DNA methylation, and ncRNAs constitute a multilayered and multifaceted circuitry for sophisticated and robust epigenetic regulation in plants, which is important for their unique developmental processes, sessile lifestyle, and evolutionary traces. Aspects of plant development that are relevant to epigenetic regulation are as follows: (1) epigenetically flexible and transmissible gametogenesis, (2) late-producing germ cells to allow for the transmission of epigenetic modifications acquired by meristem cells, (3) vegetative or clonal propagation to perpetuate mitotically transmissible epigenetic states, (4) somaclonal variation during somatic embryogenesis, (5) diffusible epigenetic signals through plasmodesmata to modify the epigenetic state of stem cells and gametes, and (6) high tolerance for polyploidization and endoreplication associated with significant genomic and epigenetic changes [34].
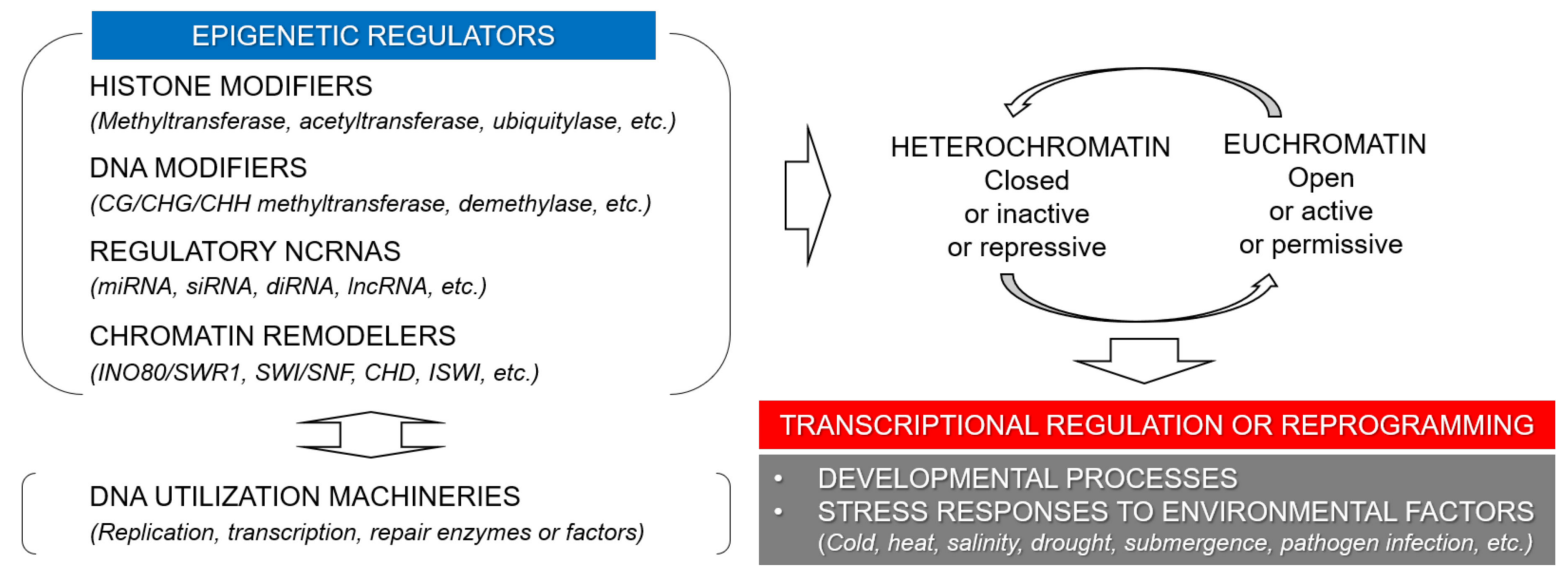

Figure 1. Epigenetic regulators mediate chromatin dynamics for transcriptional regulation or reprogramming in plant development and stress response. Histone and DNA modifiers, regulatory non-coding RNAs (ncRNAs), chromatin remodelers, and DNA utilization machineries together constitute a multilayered and multifaceted circuitry for chromatinbased transcriptional regulation in plant development and stress response.

Chromatin modifications and dynamics are necessary for genome replication, transcriptional activity, and DNA repair. The maintenance and transition of chromatin states, such as active euchromatin and repressed heterochromatin in plants, can be modulated by a variety of epigenetic regulators as well as the replication, transcription, and repair machinery (Figure 1) [35]. The epigenetic regulators identified in plants are divided into four groups: (1) chromatin remodelers (four conserved families: INO80/SWR1, SWI/SNF, CHD, and IMITATION SWITCH (ISWI)), (2) histone-modifying enzymes (methyltransferase, demethylase, acetyltransferase, deacetylase, ubiquitylase, kinase, etc.) and chaperones, (3) DNA (de)-methylation enzymes (CG/CHG/CHH methyltransferase and demethylase) and regulators, and (4) ncRNAs (miRNA, small-interfering RNA (siRNA), diRNA, and lncRNA) [13]. A nucleosome, the fundamental subunit of chromatin, consists of a histone octamer (two H2A, two H2B, two H3, and two H4) and a 147 bp DNA; therefore, the epigenetic modifiers responsible for histone modifications and DNA (de)-methylation (groups 2 and 3) are the primary epigenetic regulators in chromatin organization and its adaptability to environmental cues. Histone modifying enzymes and chaperones are highly conserved among eukaryotes, whereas the non-CG methylation at $\mathrm{CHG}$ and $\mathrm{CHH}$ sites are specific to plant genomes due to the plant-specific CHROMOMETHYLASE and RdDM pathways, 
which associate with the inverse correlation between heterochromatin and genic DNA methylation [36,37]. Groups 1 and 4 contribute to chromatin remodeling and dynamics through interactions with histone modifications and DNA methylation [13,38]. Although chromatin remodelers are somewhat conserved, they differentiate among plants, fungi and animals [39], whereas ncRNAs are the most variable epigenetic regulators $[38,40]$.

Therefore, the engineering of plant genomes to modulate plant stress responses requires an updated understanding of stress-induced transcriptions and stress memory in the context of epigenetic regulation, such as histone modifications and DNA methylation. The following sections review: (1) chromatin dynamics, especially histone modifications and DNA methylation, associated with abiotic/biotic stress-induced transcriptions in plants, (2) interplay of histone modifications, DNA methylation, and ncRNAs in stress-induced transcriptional reprogramming, and (3) chromatin-based transcriptional reprogramming for stress signaling and memory in plants.

\section{Chromatin Dynamics Associated with Abiotic Stress-Induced Transcriptions in Plants}

Transcriptionally active euchromatic regions or genes are associated with histone 3 lysine 4 (H3K4) trimethylation (H3K4me3), H3K9/H3K23/H3K29 acetylation (H3K9ac/ $\mathrm{H} 3 \mathrm{~K} 23 \mathrm{ac} / \mathrm{H} 3 \mathrm{~K} 29 \mathrm{ac}$ ), and/or CG/CHG/CHH hypomethylation [41]. Changes in histone modification and DNA methylation trigger differential expressions of stress-responsive genes to environmental cues $[2,18]$. Although the causal relationship between chromatin dynamics and transcriptional changes is still unclear for plant stress responses, there is accumulating evidence revealing the concurrent chromatin modifications in transcriptional stress responses [20,21]. The acetylation of core histones H3 and H4 is associated with transcriptional activation and generally induces a permissive chromatin structure, whereas histone deacetylation is often correlated with closed chromatin and transcriptional repression [42]. This review summarizes the recent updates that associate diverse chromatin modifications with the stress-induced transcriptions in plants under the major abiotic stresses, including cold, heat, salinity, drought, and flood (Table 1).

Cold: Cold stress in plants can be divided into two types: chilling $\left(0-15^{\circ} \mathrm{C}\right)$ and freezing (below $0{ }^{\circ} \mathrm{C}$ ). Stress responses during cold acclimation and vernalization are epigenetically regulated by histone modifications and DNA methylation [43]. The histone deacetylase inhibitor Trichostatin A and DNA methylation inhibitor 5-Aza-2'-Deoxycytidine alter the expression of cold-induced genes in Arabidopsis thaliana, enhancing its cold tolerance [44], and in response to cold stress, histone $\mathrm{H} 3$ acetylation-mediated chromatin remodeling is necessary for transcriptional activation of a cold-inducible rice gene, OsDREB1b [45]. The POWERDRESS (PWR)-HOS15-HD2C complex in Arabidopsis negatively regulates the expression of $\mathrm{COR}$ genes through $\mathrm{H} 3$ deacetylation and repressive chromatin structure $[25,46]$, whereas the histone deacetylase HD2C is degraded by the PWR-HOS15 complex, resulting in transcriptional activation of COR genes (RD29A and COR15A/47/78) under cold stress, by facilitating $\mathrm{H} 3$ acetylation and the permissive chromatin structure. In cold-treated banana (Musa acuminata) fruits, the increased levels of $\mathrm{H} 3$ and $\mathrm{H} 4$ acetylation in the promoters of $\omega-3$ fatty acid desaturase genes $(M a F A D s)$ are correlated with the enhanced transcription of $\omega-3$ MaFADs; the MaMYB4 transcription factor negatively regulates the transcription of $\omega-3$ MaFADs by recruiting the histone deacetylase MaHDA2 [47]. The bivalent histone modifications H3K4me3 and H3K27me3 enhance chromatin accessibility and facilitate the access of regulatory proteins required for transcription of active genes in cold-stored potato (Solanum tuberosum) tubers [24]. The PHD (plant homeodomain) finger of the Arabidopsis SAP and MIZ1 domain-containing ligase1 (SIZ1), a small ubiquitin-like modifier (SUMO) E3 ligase, recognizes $\mathrm{H} 3 \mathrm{~K} 4 \mathrm{me} 3$ and negatively regulates the histone lysine methyltransferase ATX1 for H3K4me3, associating the transcription and H3K4me3 levels of WRKY70 under cold stress [48]. In addition, the differentially methylated BramMDH1, BraKAT2, BraSHM4, and Bra4CL2 genes in cold-acclimated bok choy plant transcriptions demonstrate the importance of promoter demethylation [49]. The rice OsOST1 (Os03g0610900), which participates in the ICE-CBF-COR pathway for cold tolerance, also 
associates its promoter demethylation with the increased gene expression [50]. In contrast, the cold-induced expression of $D R E B 1 A$ was repressed by the transgene-induced hypermethylation in the DREB1A promoter in the Arabidopsis ice1-1 mutant [51]. The Arabidopsis ARGONAUTE1 (AGO1) promotes gene transcription by binding to the chromatin of stress-responsive genes through interaction with small RNAs and SWI/SNF chromatin remodeling complexes in response to cold or phytohormones [52].

Heat: Genetic and epigenetic controls through histone modifications, DNA methylation, chromatin remodeling, ncRNAs, and others are also involved in plant responses to heat [53]. The Arabidopsis histone acetyltransferase GCN5 mediates transcriptional activation of the heat stress-responsive HSFA3 and UVH6 genes by facilitating H3K9 and H3K14 acetylation in their promoter regions [23]. The histone chaperone ANTI-SILENCING FUNCTION1 (ASF1) A/B mediates H3K56 acetylation associated with the heat-induced activation of HSFA2 and HEAT SHOCK PROTEIN32 (HSP32) genes in Arabidopsis thaliana via nucleosome removal and RNA polymerase II (PolII) accumulation in the promoter and coding regions [54]. The Arabidopsis histone deacetylase HD2C interacts with a BRMcontaining SWI/SNF chromatin remodeling complex through SWI3B, and represses the heat-activated HSFA3 and HSP101 genes by decreasing H4K16ac levels within their coding regions [55]. In contrast, the heat-induced transcription factor HSFA2 directly activates the H3K27me3 demethylase RELATIVE OF EARLY FLOWERING6 (REF6), which derepresses HSFA2 to establish a heritable feedback loop generating transgenerational thermomemory in Arabidopsis [56]. After acclimatizing heat stress, the HSFA2 transcription factor directly associates with the promoter of the heat stress memory-related genes APX2 and HSP18.2 and facilitates the sustained accumulation of $\mathrm{H} 3 \mathrm{~K} 4 \mathrm{me} 2 / 3$ at these gene loci as a transcriptional memory for hyper-induction of these genes during recurring heat stress [57,58]. Another H3K36 trimethylation, which is mediated by the histone methyltransferases SET DOMAIN GROUP8 (SDG8) and SDG26, is crucial for the processes of alternative splicing and flowering in Arabidopsis in response to fluctuating ambient temperature [59]. The Arabidopsis RdDM factor NRPD2, the second-largest subunit of PolIV and PolV, participates in transcriptional reprogramming of At1g34220, At1g07590, At1g29475, and auxin-responsive genes in response to temperature stress [60]. The de novo DNA methyltransferase DRM2 and the largest subunits of PolIV (NRPD1) and PolV (NRPE1) genes, which are key players in the RdDM pathway, are upregulated in Arabidopsis under heat stress, and the heatinduced expression of At3g50770 is associated with reduced promoter methylation [61]. In bok choy, heat-induced DMRs are generally located near the transcription start and end sites of gene-related regions and differentially correlate with gene expression, indicating CG/CHG/CHH context- and position-dependent transcriptional silencing [27]. During vegetative growth, the Arabidopsis thaliana imprinted gene SDC is suppressed by DNA methylation but is activated by heat stress, revealing its role in heat stress recovery [62]. In contrast, Arabidopsis FORGETTER1 (FGT1) binds to the proximal promoter of the heatresponsive $H S A 32$ and $H S P 18.2 / 22.0$ genes through nucleosome remodeling by interaction with SWI/SNF (BRM) and ISWI (CHR11/17) family chromatin remodelers and contributes to the sustainable induction of these genes after acclimatizing heat stress [63]. 
Table 1. Chromatin dynamics (histone modifications and DNA methylation changes) associated with abiotic stress-induced gene expression in plants.

\begin{tabular}{|c|c|c|c|c|c|}
\hline Stress Type & $\begin{array}{l}\text { Chromatin Modifications } \\
\text { Tested }\end{array}$ & Epigenetic Modifiers Tested & Species & Genes Associated & Reference \\
\hline \multicolumn{6}{|l|}{ Abiotic stress } \\
\hline \multirow{8}{*}{ Cold } & Н3К9/14/27ac & & Oryza sativa & OsDREB1b & [45] \\
\hline & $\mathrm{H} 3 \mathrm{~K} 9 / 14 \mathrm{ac}$ & PWR-HOS15-HD2C & Arabidopsis thaliana & $R D 29 A, C O R 15 A / 47 / 78$ & {$[23,46]$} \\
\hline & $\mathrm{H} 3 / \mathrm{H} 4 \mathrm{ac}$ & MYB4, HDA2 & Musa acuminata & MaFADs & [47] \\
\hline & H3K4/27me3 & & Solanum tuberosum & Cold-responsive genes & [24] \\
\hline & H3K4me3 & SIZ1, ATX1 & Arabidopsis thaliana & WRKY70 & [48] \\
\hline & 5-mC in promoter & & Brassica rapa & BramMDH1, BraKAT2, BraSHM4, Bra4CL2 & [49] \\
\hline & 5 -mC in promoter & & Oryza sativa & OsOST1 (Os03g0610900) & [50] \\
\hline & 5 -mC in promoter & & Arabidopsis thaliana & DREB1A & [51] \\
\hline \multirow{10}{*}{ Heat } & H3K9/14ac & GCN5 & Arabidopsis thaliana & HSFA3, UVH6 & [23] \\
\hline & H3K56ac & ASF1 & Arabidopsis thaliana & HSFA2, HSP32 & [54] \\
\hline & H3K16ac & HD2C, BRM & Arabidopsis thaliana & HSFA3, HSP101 & [55] \\
\hline & H3K27me3 & REF6, HSFA2 & Arabidopsis thaliana & HSFA2 & [56] \\
\hline & $\mathrm{H} 3 \mathrm{~K} 4 \mathrm{me} 2 / 3$ & HSFA2 & Arabidopsis thaliana & $A P X 2$ and $H S P 18.2$ & {$[57,58]$} \\
\hline & H3K36me3 & SDG8/26 & Arabidopsis thaliana & Genes subjected to alternative splicing & [59] \\
\hline & $5-\mathrm{mC}$ & NRPD2 & Arabidopsis thaliana & At1g34220, At1g07590, At1g29475, auxin-responsive genes & {$[60]$} \\
\hline & 5 -mC in promoter & DRM2, NRPD1, NRPE1 & Arabidopsis thaliana & At3g50770 & [61] \\
\hline & $5-\mathrm{mC}$ & & Arabidopsis thaliana & $S D C$ & [62] \\
\hline & Chromatin remodeling & FGT1, BRM, CHR11/17 & Arabidopsis thaliana & HSA32, HSP18.2/22.0 & [63] \\
\hline \multirow{17}{*}{ Salinity } & \multicolumn{2}{|l|}{ 5-mC, H3K9me2, H3K9ac } & Arabidopsis thaliana & SUVH2/5/8, ROS1, MSH6, APUM3, MOS6, DRB2 & [64] \\
\hline & \multicolumn{2}{|l|}{$\begin{array}{l}\text { 5-mC, H3K4me3, H3K9ac, } \\
\text { H3K9me2 }\end{array}$} & Glycine max & Glyma11g02400, Glyma08g41450, Glyma20g30840 & {$[65]$} \\
\hline & Н3К9ас & & Zea mays & $\mathrm{ZmEXPB2,} \mathrm{ZmXET1}$ & [66] \\
\hline & H3K9/14ac & GCN5 & Arabidopsis thaliana & CTL1, PGX3, MYB54 & [22] \\
\hline & H3K27/36/56ac, H4ac, H3K9me2 & PWR-HOS15-HDA9 & Arabidopsis thaliana & ERF4/5/6/11, STZ, KIN2 & [67] \\
\hline & НЗас & HDA1, IDS1, TPR1 & Oryza sativa & LEA1, SOS1 & [68] \\
\hline & H3ac & HDA5/14/15/18/19 & Arabidopsis thaliana & ABI5, NCED4, GA20 × 7,LEA4_2, P5CS1, NAC016/019 & {$[69,70]$} \\
\hline & H4R3sme2 & SKB1 & Arabidopsis thaliana & FLC, HAB1, MEK1, MEKK1, MRK1 & [71] \\
\hline & H3K4me2/3 & JMJ15 & Arabidopsis thaliana & WRKY33, ERF6 & [72] \\
\hline & H3K4me3 & & Arabidopsis thaliana & P5CS1 & [73] \\
\hline & H3K4/27me3 & & Ricinus communis & RSM1 & [74] \\
\hline & H3K4/27me3 & AGO2 & Oryza sativa & $B G 3$ & [75] \\
\hline & H2Bub & $\mathrm{HUB} 1 / 2, \mathrm{UBC} 1 / 2 / 3$ & Arabidopsis thaliana & PTP1, DsPTP1, MKP1, IBR5, PHS1 & [76] \\
\hline & 5 -mC in promoter & 24-nt siRNAs & Arabidopsis thaliana & AtMYB74 & [77] \\
\hline & 5 -mC in coding regions & & Triticum aestivum & TaHKT2;1/2;3 & [78] \\
\hline & 5 -mC in promoter & & Medicago truncatula & $L E A, A P 2 / E R F, K A T 3, b Z I P, W R K Y, N A C$ & [79] \\
\hline & $5-\mathrm{mC}$ & SUVH7-BAG4-MYB106 & Oryza sativa & OsHKT1;5 & [80] \\
\hline
\end{tabular}


Table 1. Cont.

\begin{tabular}{|c|c|c|c|c|c|}
\hline Stress Type & $\begin{array}{l}\text { Chromatin Modifications } \\
\text { Tested }\end{array}$ & Epigenetic Modifiers Tested & Species & Genes Associated & Reference \\
\hline \multirow{9}{*}{$\begin{array}{l}\text { Drought } \\
\text { or dehydration }\end{array}$} & H3K9ac, H3K4me3 & \multirow{2}{*}{ AREB1, ADA26-GCN5 } & Arabidopsis thaliana & RD20, RD29a, AtGOLS2, ProDH & [81] \\
\hline & Н3К9ас & & Populus trichocarpa & PtrNAC006, PtrNAC007, PtrNAC120 & [82] \\
\hline & H3К27ac & HAT1 & Arabidopsis thaliana & AtAREB1 & [83] \\
\hline & $\mathrm{H} 3 / \mathrm{H} 4 \mathrm{ac}$ & MYB96, HDA15 & Arabidopsis thaliana & $R O P 6 / 10 / 11$ & [84] \\
\hline & Н3К9ас & HDA9 & Arabidopsis thaliana & Water deprivation-responsive genes & [85] \\
\hline & Histone acetylation & HDA9 & Arabidopsis thaliana & CYP707A1/2 & {$[86,87]$} \\
\hline & $\mathrm{H} 3 \mathrm{~K} 4 \mathrm{me} 3, \mathrm{H} 3 \mathrm{~K} 9 \mathrm{me} 2$ & & Hordeum vulgare & HSP17 & {$[88]$} \\
\hline & H3K4me3 & & Arabidopsis thaliana & LTP3, LTP4, HIPP2.2 & [89] \\
\hline & H3K4me3 & JMJ17 & Arabidopsis thaliana & OST1, ABF3, ATHB7, ERD1 & {$[90]$} \\
\hline \multirow{8}{*}{$\begin{array}{l}\text { Submergence } \\
\text { or waterlogging } \\
\text { or others }\end{array}$} & H3K4me3, H3ac & \multirow{7}{*}{ AGO1 } & Oryza sativa & $A D H 1, P D C 1$ & [91] \\
\hline & $\mathrm{H} 3 / \mathrm{H} 4 \mathrm{ac}$ & & Triticum aestivum & $C E L, P G, X E T$ & [92] \\
\hline & 5-mC, H3K27me3 & & Arabidopsis thaliana & ASK11, CYP71A13, DREB19, AOX1D, At1g68620, ACS2 & [93] \\
\hline & $5-\mathrm{mC}$ & & Sesamum indicum & Drought and waterlogging-responsive genes & [94] \\
\hline & $5-\mathrm{mC}$ & & Arabidopsis thaliana & HR4 & [95] \\
\hline & $5-\mathrm{mC}$ & & Oryza sativa & Cd-responsive genes & [96] \\
\hline & H3K4me3, H3ac & & Arabidopsis thaliana & CIPK11, RPA1E, GMI1, RAD51, AGO2 & [97] \\
\hline & $\mathrm{H} 3 \mathrm{~K} 14 \mathrm{ac}$ & C/S1-bZIP-SnRK1 & Arabidopsis thaliana & ETFQO & [98] \\
\hline
\end{tabular}


Salinity: Salinity and drought stress also induces histone modification and DNA methylation changes, which modify the chromatin organization and dynamics to facilitate locus-specific gene expression in the genome in plants [99]. In the progeny of salt-stressed Arabidopsis plants, the lower expression levels of SUVH2/5/8, ROS1, MSH6, APUM3, MOS6, and DRB2 genes can be associated with DNA hypermethylation, H3K9me2 enhancement, and/or H3K9ac depletion in the promoter or coding regions [64]. The soybean (Glycine max) genes Glyma11g02400, Glyma08g41450, and Glyma20g30840, are regulated by increased $\mathrm{H} 3 \mathrm{~K} 4 \mathrm{me} 3$ and $\mathrm{H} 3 \mathrm{~K} 9 \mathrm{ac}$, reduced $\mathrm{H} 3 \mathrm{~K} 9 \mathrm{me} 2$ as well as DNA hypermethylation [65]. Root swelling in maize (Zea mays) during salinity stress is related to the up-regulation of the cell wall-related genes ZmEXPB2 and ZmXET1, associating with the elevated H3K9ac levels in the promoter and coding regions [66]. The Arabidopsis and wheat (Triticum aestivum) histone acetyltransferases AtGCN5 and TaGCN5 contribute to the expression of cellulose synthesis genes CTL1, PGX3, and MYB54, which are also associated with cell wall integrity and salt tolerance, by facilitating $\mathrm{H} 3 \mathrm{~K} 9$ and H3K14 acetylation [22]. In contrast, HDA9 constitutes a core histone deacetylase complex with PWR and HOS15, that binds to and directly represses many abiotic/biotic stress-responsive genes, including ethylene response factor (ERF) (ERF4/5/6/11), salt tolerance zinc finger (STZ), and kinase 2 (KIN2) genes, by modulating both histone acetylation (H3K27ac/H3K36ac/H3K56ac, H3.3K27/36ac and $\mathrm{H} 4 \mathrm{ac}$ ) and methylation (H3K9me2 and H3.1K36me2) [67]. Another histone deacetylase HDA1 induces the transcriptional repression of LATE EMBRYOGENESIS ABUNDANT PROTEIN1 (LEA1) and SALT OVERLY SENSITIVE1 (SOS1) in rice by decreasing H3 acetylation and interacting with the apetala2/ERF transcriptional repressors INDETERMINATE SPIKELET1 (IDS1) and TOPLESS-RELATED1 (TPR1) in the promoter regions of LEA1 and SOS1 genes, which are crucial for salt tolerance in rice [68]. The Arabidopsis class I (HDA19) and class II (HDA5/14/15/18) REDUCED POTASSIUM DEPENDENCY3 (RPD3)-like family histone deacetylases control positive and negative salinity stress responses, respectively, by acting conversely in the expressions of salt-responsive genes, such as ABI5, NCED4, GA20x7, LEA4_2, P5CS1, and NAC016/019 [69,70]. In addition, the enhanced gene expression of six histone deacetylases HcHDA2, HcHDA6, HcHDA8, HcHDA9, HcHDA19, and HcSRT2 in kenaf (Hibiscus cannabinus) during salinity stress is associated with the levels of H3K9ac, H3K27ac, and H4K5ac, but has not yet been linked to other stress-induced transcriptional responses [100]. The Arabidopsis floral initiator Shk1 kinase binding protein1 (SKB1), a type II arginine methyltransferase, regulates transcription and pre-mRNA splicing of FLOWERING LOCUS C (FLC) and the stress-responsive genes, such as HAB1, $M E K 1, M E K K 1$, and MRK1, during salinity stress by dissociating from chromatin and altering the methylation status of histone 4 arginine 3 (H4R3) symmetric demethylation (H4R3sme2) and small nuclear ribonucleoprotein Sm-like4 (LSM4) [71]. Over-expression of the Arabidopsis H3K4 demethylase JMJ15 gene down-regulates genes of stress-responsive transcription regulators, such as WRKY33 and ERF6, which are marked with H3K4me2/3, thereby enhancing salt tolerance by modulating the expression of salinity-responsive genes, such as RD29A, RD22, and COR15 [72]. In contrast, the salinity-induced transcriptional memory of $\Delta^{1}$-pyrroline-5-carboxylate synthetase1 (P5CS1) for proline accumulation under chronic salinity stress is directly associated with light-dependent HY5 binding and the increased H3K4me3 level at the P5CS1 promoter [73]. The bivalent H3K4me3 and H3K27me3 modifications contribute to the transcriptional regulation of the key salinity-response regulator RADIALIS-LIKE SANT (RSM1), an MYB-related transcription factor involved in salt stress signaling in castor bean (Ricinus communis) [74]. Salinity stress in rice causes the AGO2 proteins to be enriched on the BIG GRAINS3 (BG3) locus under salinity stress and promotes the $B G 3$ expression by increasing H3K4me3 and decreasing H3K27me3 [75]. The Arabidopsis histone H2B monoubiquitination (H2Bub) mediated by two RING E3 ligases HUB1/2 and three E2 conjugases UBC1/2/3, regulates the expression of PROTEIN TYROSINE PHOSPHATASE1 (PTP1) and MAP KINASE PHOSPHATASE (MKP) genes, including DsPTP1, MKP1, IBR5, and PHS1, required for salinity-induced microtubule depolymerization, and affects the activation of mitogen-activated protein kinase3 (MPK3) 
and MPK6 in salinity stress [76]. The salt-induced transcription factor AtMYB74, is transcriptionally regulated by the reduced levels of 24-nt siRNAs and RdDM in the promoter in Arabidopsis during stress conditions [77]. Salinity stress modulates the cytosine methylation and gene expression patterns in crop plants, including rice, barley (Hordeum vulgare), wheat (Triticum aestivum), and olive (Olea europaea), depending on the genotypes and tissue types $[26,78,101-103]$. Cytosine methylation in wheat (Triticum aestivum), which is induced by excess salinity, downregulates the expression of Triticum aestivum HIGH-AFFINITY POTASSIUM TRANSPORTER2;1 (TaHKT2;1) and TaHKT2;3 in the shoot and root tissues of the salt-tolerant genotypes, whereas TaHKT1;4 is not affected [78]. In addition, the expression levels of salinity-responsive genes, such as LEA, AP2 /ERF, KAT3, bZIP, WRKY, and NAC in caliph medic (Medicago truncatula) are somewhat associated with the altered cytosine methylation levels in the promoter regions [79]. The rice DNA methylation reader (OsSUVH7)-chaperone regulator (OsBAG4)-transcription factor (OsMYB106) complex activates the expression of OsHKT1;5 under salinity stress by binding to the MYB binding cis-element (MYBE) as well as the miniature inverted-repeat transposable element (MITE) upstream of the MYBE in the OsHKT1;5 promoter [80].

Drought or dehydration: Dynamic modifications of chromatin composition and organization also influence the regulation of transcription and stress responses in plants during drought stress and recovery $[28,99,104]$. In maize, variations in the euchromatic marks $\mathrm{H} 3 \mathrm{~K} 9 \mathrm{ac}$ and $\mathrm{H} 3 \mathrm{~K} 4 \mathrm{me} 3$ are associated with stress-induced gene expression in response to drought and recovery [104]. Chromatin dynamics through H3K9ac and H3K4me3 are correlated with the transcriptional activation and repression of the drought-inducible RD20, RD29a, AtGOLS2 and the rehydration-inducible ProDH genes in Arabidopsis during drought stress and subsequent recovery [81]. The ISWI-responsive element (ABRE) binding protein1 (AREB1), which binds to ABRE motifs in promoters of the drought-responsive genes PtrNAC006/007/120, increases H3K9ac and PolII at these PtrNAC genes by recruiting the histone acetyltransferase unit ADA26-GCN5, which regulates drought response and tolerance in Populus trichocarpa [82]. Improved drought tolerance in Arabidopsis can be achieved by positively regulating the gene expression of AREB1 through H3K27ac enhancement at the promoter by the CRISPR/dCas9 system fused with histone acetyltransferase1 (HAT1) [83]. The Arabidopsis MYB96 transcription factor, which interacts and acts synergistically with the histone deacetylase HDA15 in ABA signaling, represses the expression of RHO GTPASE OF PLANTS (ROP) genes ROP6/10/11 under drought stress by decreasing $\mathrm{H} 3$ and $\mathrm{H} 4$ acetylation at these promoters [84]. In contrast, the Arabidopsis histone deacetylase HDA9 negatively regulates plant responsiveness to both salinity and drought stresses by decreasing H3K9 acetylation levels in the promoters of many responsive genes [85]. The histone deacetylase HDA9 interacts with the ABA INSENSITIVE (ABI4) transcription factor and binds to the promoters of the ABA catabolism-related genes CYP707A1/2 to repress the expression of CYP707s through histone deacetylation under drought stress [86,87]. Increased H3K4me3 and reduced H3K9me2 modifications at the coding regions of HSP17 are associated with the HSP17 expression in drought-treated barley plants [88]. When the stress-responsive genes are induced or repressed during dehydration stress in Arabidopsis, the H3K4me3 level at these genes is substantially altered compared to the moderate changes in the H3K4me1 and H3K4me2 levels [105]. The dehydration stress memory genes LTP3, LTP4, and HIPP2.2, which are super-induced during the recurrent dehydration stress in Arabidopsis, are also associated with the increased H3K4me3 and PolII levels at these genes during recovery from the initial stress [89]. The elevated H3K27me3 levels, which are mediated by the methyltransferase CLF and repress the flower-specific gene AGAMOUS ( $A G$ ) at the vegetative stage, do not interfere with the transition to active transcription or with $\mathrm{H} 3 \mathrm{~K} 4 \mathrm{me} 3$ accumulation during dehydration stress memory. The Arabidopsis histone demethylase JMJ17, which belongs to the KDMS/JARID12 family and demethylates $\mathrm{H} 3 \mathrm{~K} 4 \mathrm{me} 1 / 2 / 3$, negatively regulates the stress-responsive genes OST1, ABF3, $A T H B 7$, and ERD1 under dehydration stress by demethylating H3K4me3 at those gene loci [90]. Drought-induced genome-wide DNA methylation changes are associated with 
differential transcription between contrasting rice genotypes in drought stress responses, depending on the genotype, development, and tissue specificity $[26,106,107]$. DNA methylation alterations during drought stress are restored to near-normal states during recovery in rice, Eucalyptus globulus, Citrus sinensis, and cotton (Gossypium hirsutum), and these methylation variations are found in many hormone-related genes associated with the drought stress response [106,108-110]. The genome-wide DNA methylation in Arabidopsis reacts strongly to water deprivation and the predominant changes are located at loci in the promoters of drought-responsive genes [111]. However, there are insufficient data to demonstrate a causal relationship between the gene- or locus-specific DNA methylation and the transcriptional changes of drought-responsive genes. Drought-associated epialleles in the DNA methylome are negligible and cannot be correlated with the drought-responsive gene expression under transgenerational drought stress, even in Arabidopsis [112].

Submergence or waterlogging or others: The diametric environmental water stresses drought and flood extremely affect water availability in plants, threatening food security, yet flood stresses, including submergence and waterlogging, are relatively understudied at the molecular level [113]. Since chromatin modifications and epigenetic regulation in water stress responses have been explored mainly under drought or dehydration conditions, there are limited available data to associate the chromatin-based transcriptional regulation with submergence or waterlogging stress responses [114,115]. One of the few studies revealed that the rice submergence-inducible $A D H 1$ and $P D C 1$ genes are activated during submergence by dynamic and reversible H3K4 trimethylation and $\mathrm{H} 3$ acetylation and increased binding of PolII at these genes [91]. Histone lysine butyrylation and crotonylation, along with acetylation, are dynamically regulated as a putative epigenetic mechanism for refining gene expression in rice under submergence [116]. The H3 and $\mathrm{H} 4$ acetylation in wheat seminal roots under waterlogging is positively associated with the increased transcription levels of the endoglucase $(C E L)$, polygalacturonase $(P G)$, and xyloglucan endotransglucosylase (XET) genes, which affect cell wall degradation and aerenchyma formation [92]. The age-regulated genes ASK11, CYP71A13, DREB19, AOX1D, At1g68620, and ACS2, which are induced under submergence by the ROS-activated transcription factor ANAC017, are more highly expressed in juvenile Arabidopsis plants than in adult ones, with lower promoter methylation and H3K27 trimethylation levels [93]. In sesame (Sesamum indicum), a drought-tolerant crop sensitive to waterlogging, drought stress strongly induces de novo DNA methylation, whereas flood stress decreases the level of DNA methylation, allowing a strong correlation between the transcript levels and methylation patterns of responsive genes [94]. The AGO1-dependent repression of the HOMOLOG OF RPW8 4 (HR4) gene in Arabidopsis under submergence-induced hypoxia is associated with the AGO4-dependent RdDM pathway [95]. In addition, there is much evidence available to demonstrate the chromatin-based regulation of gene expression under other abiotic stresses. Heavy metal stress to cadmium (Cd) in rice causes transcriptional alteration of most of the DNA methylation-modified genes, including GSH2, GSH35, LOX, HO1, OsIRO2, OsZIP1, HMT, CTF, Os09g02214, and OsSPL1 [96]. The Arabidopsis DNA damage response genes CIPK11, RPA1E, GMI1, RAD51, and AGO2 are transcriptionally activated by the increased $\mathrm{H} 3 \mathrm{~K} 4 \mathrm{me} 3$ and/or H3K9ac levels under genotoxic stress [97]. The ELECTRON-TRANSFER FLAVOPROTEIN:UBIQUINONE OXIDO-REDUCTASE (ETFQO) gene involved in branched-chain amino acid catabolism, an alternative mitochondrial respiratory pathway under carbohydrate-limiting conditions, is positively regulated in Arabidopsis during dark-induced starvation by the C/S1-bZIP-SnRK1 complex-facilitated enhancement of H3K14ac in the ETFQO promoter [98]. Overall, it is evident that chromatin modifications and epigenetic regulation are crucial to plant DNA damage responses, which are imposed by abiotic and biotic stress factors [13].

\section{Chromatin Dynamics Associated with Biotic Stress-Induced Transcriptions in Plants}

The main environmental biotic threats to plants include herbivores and microbial pathogens, and the latter is deservedly the primary biotic stress factor. Histone modifi- 
cations $\mathrm{H} 3 / \mathrm{H} 4$ acetylation, H3K4/H3K9/H3K27 methylation, H2B ubiquitination, DNA methylation, and chromatin remodeling are the main chromatin-based epigenetic mechanisms regulating the chromatin dynamics required for transcriptional activation and repression in plant biotic stress responses, such as plant-microbe interactions and plant immunity [19,117-120]. For example, H3/H4 lysine methylation and acetylation are associated with the transcriptional activation of the defense genes WRKY6/29/53 in Arabidopsis leaves with inoculation of Pseudomonas syringae pv. maculicola (Psm) [30]. The gene expression of PATHOGENESIS-RELATED GENE1 (PR1) in Arabidopsis upon pathogen infection is positively regulated by the SA-mediated $\mathrm{H} 3 / \mathrm{H} 4 \mathrm{ac}$ and $\mathrm{H} 3 \mathrm{~K} 4 \mathrm{me} 2 / 3$ enhancement associated with diverse transcription factors at the PR1 promoter [121]. SA is the major plant defense hormone against biotrophic and hemibiotrophic pathogens. Chromatin dynamics through H3K27me3 enrichment also contributes to transcriptional derepression for the spatiotemporal expression of virulence genes in the fungal wheat pathogen Zymoseptoria tritici after the initial stages of infection [122]. However, this review highlights the recent updates on chromatin-based transcriptional regulation in plant defense responses to pathogens, as opposed to virulence development of pathogens (Table 2).

The Arabidopsis elongator complex subunit2 (ELP2) and ELP3, which are important for both basal immunity and effector-triggered immunity (ETI), but are not involved in systemic acquired resistance (SAR), positively regulate the transcriptional induction of defense genes PR1/2/5 through dynamic changes in histone acetylation and DNA methylation [123]. The histone acetyltransferase GCN5 is the catalytic subunit of the nucleosomeacetylating complex SPT-ADA2-GCN5 (SAGA). The cytoplasmic effect PsAvh23 of the soybean pathogen Phytophthora sojae suppresses the activation of defense-related genes PGIP1, HSP20/90, WRKY33/41, NAC, and MAPKKK14/18 during infection by interfering with the association of ADA2 with GCN5 and decreasing H3K9 acetylation at these genes [124]. As a redox-signaling molecule, NO is induced by SA and affects histone acetylation by targeting and inhibiting histone deacetylase complexes, resulting in the hyperacetylation of specific genes, such as MKK2, PNC2, BAG6, AIG2, TRX3, WRKY27/53, and TGA2/5 [125]. The effector HC-toxin (HCT) of the fungal pathogen Cochliobolus carbonum race 1 modulates both histone and non-histone protein acetylation by inhibiting histone deacetylase, also promoting virulence in maize [126]. The Arabidopsis histone deacetylase HD2B, which binds to and is phosphorylated by the MAP kinase MPK3 to modulate its subnuclear localization and target genes, contributes to the transcriptional repression of biotic stress response genes, including At1g80180, At4g31470, At1g49640, and At5g01740 through H3K9 deacetylation in response to flagellin [127]. In contrast, the HDA6, an RPD3/HDA1-type deacetylase, acts as a general repressor of pathogen defense response by negatively regulating the histone acetylation and the expression of pathogen-responsive genes, including PR1/2 and WRKY38 in Arabidopsis with or without pathogen infection of the hemibiotrophic bacterial pathogen Pseudomonas syringae pv. tomato (Pst) DC3000 [128]. The Arabidopsis histone methyltransferases SDG8 and SDG25 participate in plant immunity at multiple levels, such as pattern-triggered immunity (PTI), ETI, and SAR in response to bacterial and fungal pathogens [129]. The SDG8 and SDG25 regulate the expression of CAROTENOID ISOMERASE2 (CCR2) and ECERIFERUM3 (CER3) genes, which are involved in the biosynthesis of carotenoid and cuticular wax, required for plant immunity, by inducing locus-specific $\mathrm{H} 3 \mathrm{~K} 4 / 36$ methylations and $\mathrm{H} 2 \mathrm{~B}$ ubiquitination at these genes. Another H3K4 methyltransferase, Arabidopsis Trithorax-Related7 (ATXR7), activates the expression of the pathogen-responsive RECOGNITION OF PERONOSPORA PARASITICA4 (RPP4) and SUPPRESSOR OF npr1-1 CONSTITUTIVE1 (SNC1) genes encoding nucleotidebinding leucine-rich repeat (NB-LRR) proteins through H3K4 methylation, in association with MOS9 [130]. The rice histone lysine demethylase JMJ704, a positive regulator of rice bacterial blight resistance, suppresses the transcription of the rice defense negative regulator genes, such as NRR, OsWRKY 62 and Os-11N3, by reducing the active H3K4me2/3 marks at these loci in response to Xanthomonas oryzae pv. oryzae [131]. Similarly, the Arabidopsis H3K9 histone demethylase JMJ27 negatively regulates the expression of WRKY25, a 
defense repressor gene, in response to Pst DC3000, but positively modulates the PR1/3/4/5 transcription, both through H3K9 demethylation [132]. Another histone demethylase INCREASE IN BONSAI METHYLATION1 (IBM1) facilitates the transcriptional activation of defense marker genes PR1/2 and FRK1 in Arabidopsis with Pst DC3000 infection, allowing a permissive chromatin at these genes by increasing the active $\mathrm{H} 3 \mathrm{~K} 4 \mathrm{me} 3$, and reducing the inactive H3K9me2 marks [133]. In addition, the rice BRHIS1, an SNF2 ATPase, which constitutes an SWI/SNF2 chromatin remodeling complex and is downregulated by the rice blast fungal pathogen Magnaporthe oryzae, suppresses the innate expression of defenserelated OsPBZc and OsSIRK1 genes through specific interaction with monoubiquitinated H2A.Xa/H2A.Xb/H2A.3 and H2B.7 variants in the absence of pathogen infection [134]. The Arabidopsis histone variant $\mathrm{H} 2 \mathrm{~A} . \mathrm{Z}$ is monoubiquitinated by the Polycomb Repressive Complex1 (PRC1) components AtBMIA/B/C, and this modification can be associated with transcriptional repression [135]. The chromatin-remodeling factor CHR5 in Arabidopsis contributes antagonistically to the upregulation of the immune receptor gene SNC1, with another chromatin remodeler DECREASED DNA METHYLATION1 (DDM1), and independently with a histone monoubiquitinase HUB1 [136].

As an epigenetic mark associated with chromatin dynamics in the genome, DNA methylation patterns are related to transcriptional regulation of genes as well as transposons and repetitive sequences in both host plants and plant pathogens [137,138]. Dynamic changes in DNA methylation of transposons or repetitive sequences can regulate not only their transcriptions but also those of neighboring genes in the SA-induced immune response of Arabidopsis [139]. Epigenetic quantitative trait loci (epiQTLs) in Arabidopsis are pericentromeric regions, and DNA hypomethylation in these loci contributes to the genome-wide priming of defense-related genes associated with quantitative disease resistance [140]. However, there are no cis-regulated defense genes in the resistance epiQTLs; therefore, the differentially methylated defense genes of Arabidopsis in response to the biotrophic pathogen Hyaloperonospora arabidopsidis ( $\mathrm{Hpa}$ ) are mainly trans-regulated by DNA (de)methylation [141]. In addition, the DMR-associated genes in watermelon (Citrullus lanatus) inoculated with Cucumber green mottle mosaic virus demonstrate no clear correlation between DNA methylation and gene expression [142]. By contrast, there are a few recent updates showing the relationship between the gene- or locus-specific DNA methylation patterns and the transcriptional levels of pathogen-responsive genes in plants. Dynamic DNA methylation and H3K9/14 acetylation changes induced by Arabidopsis ELP2 regulate the expression of NONEXPRESSOR OF PATHOGENESIS-RELATED GENES1 (NPR1) and PHYTOALEXIN DEFICIENT4 (PAD4) genes, which encode key regulators of plant immunity, during avirulent Pst infection [143]. DNA methylation is not directly linked with the expression of SA-induced defense genes NPR1, StWRKY1, or PR1 in potatoes, whereas $R 3 a$ promoter hypomethylation is required for its enhanced expression, contributing to the intergenerational defense priming to Phytophthora infestans (P. infestans) [144]. A cluster of disease resistance (R) genes encoding NB-LRR proteins can be regulated by the RdDM-mediated transcriptional silencing mechanism in the common bean (Phaseolus vulgaris) and rice $[145,146]$. In the wheat diploid progenitor, Aegilops tauschii infected by the biotrophic fungus Blumeria graminis f. sp. tritici $(B g t)$, the upregulation of a pathogenesis-related defense gene AeGlu is attributed to $\mathrm{CHH}$ hypomethylation in the promoter [147]. The increased transcription of ENHANCED DISEASE SUSCEPTIBILITY1 (EDS1) in melatonin-treated grape (Vitis vinifera) berries with enhanced resistance to the necrotrophic fungus Botrytis cinerea (B. cinerea) also correlates with its decreased promoter methylation level [148]. 
Table 2. Chromatin dynamics (histone modifications and DNA methylation changes) associated with biotic stress-induced gene expression in plants.

\begin{tabular}{|c|c|c|c|c|c|}
\hline Stress Type & Chromatin Modifications Tested & Epigenetic Modifiers Tested & Species & Genes Associated & Reference \\
\hline Biotic stress & $\begin{array}{l}\mathrm{H} 3 / \mathrm{H} 4 \mathrm{ac}, \mathrm{H} 3 / \mathrm{H} 4 \mathrm{me} \\
\text { H3/H4ac, H3K4me2/3, H3K9me2 } \\
\text { Histone acetylation, 5-mC } \\
\text { H3K9ac } \\
\text { H3K9/14ac } \\
\text { H3K9ac } \\
\text { H3ac } \\
\text { H3K4/36me1/2/3, H2Bub } \\
\text { H3K4me3 } \\
\text { H3K4me2/3 } \\
\text { H3K9me2 } \\
\text { H3K4me3, H3K9me2 } \\
\text { H2A.Xa/H2A.Xb/H2A.3/H2B.7ub } \\
\text { Chromatin remodeling } \\
\text { 5-mC } \\
\text { 5-mC in promoter } \\
\text { 5-mC } \\
\text { 5-mC } \\
\text { 5-mC in promoter }\end{array}$ & $\begin{array}{l}\text { ELP2/3 } \\
\text { PsAvh23, ADA2, GCN5 } \\
\text { NO } \\
\text { HD2B } \\
\text { HDA6 } \\
\text { SDG8/25 } \\
\text { ATXR7, MOS9 } \\
\text { JMJ704 } \\
\text { JMJ27 } \\
\text { IBM1 } \\
\text { BRHIS1 } \\
\text { CHR5 } \\
\text { ELP2 }\end{array}$ & $\begin{array}{l}\text { Arabidopsis thaliana } \\
\text { Arabidopsis thaliana } \\
\text { Arabidopsis thaliana } \\
\text { Glycine max } \\
\text { Arabidopsis thaliana } \\
\text { Arabidopsis thaliana } \\
\text { Arabidopsis thaliana } \\
\text { Arabidopsis thaliana } \\
\text { Arabidopsis thaliana } \\
\text { Oryza sativa } \\
\text { Arabidopsis thaliana } \\
\text { Arabidopsis thaliana } \\
\text { Oryza sativa } \\
\text { Arabidopsis thaliana } \\
\text { Arabidopsis thaliana } \\
\text { Solanum tuberosum } \\
\text { Phaseolus vulgaris } \\
\text { Aegilops tauschii } \\
\text { Vitis vinifera }\end{array}$ & $\begin{array}{l}\text { WRKY6/29/53 } \\
\text { PR1 } \\
\text { PR1/2/5 } \\
\text { PGIP1, HSP20/90, WRKY33/41, NAC, MAPKKK14/18 } \\
\text { MKK2, PNC2, BAG6, AIG2, TRX3, WRKY27/53, TGA2/5 } \\
\text { At1g80180, At4g31470, At1g49640, At5g01740 } \\
\text { PR1/2, WRKY38 } \\
\text { CCR2, CER3 } \\
\text { RPP4, SNC1 } \\
\text { NRR, OsWRKY62, Os-11N3 } \\
\text { WRKY25, PR1/3/4/5 } \\
\text { PR1/2, FRK1 } \\
\text { OsPBZc, OsSIRK1 } \\
\text { SNC1 } \\
\text { NPR1, PAD4 } \\
\text { R3a } \\
\text { NB-LRR } \\
\text { AeGlu } \\
\text { EDS1 }\end{array}$ & $\begin{array}{l}{[30]} \\
{[121]} \\
{[123]} \\
{[124]} \\
{[125]} \\
{[127]} \\
{[128]} \\
{[129]} \\
{[130]} \\
{[131]} \\
{[132]} \\
{[133]} \\
{[134]} \\
{[136]} \\
{[143]} \\
{[144]} \\
{[145,146]} \\
{[147]} \\
{[148]}\end{array}$ \\
\hline
\end{tabular}




\section{Interplay of Histone Modifications, Chromatin Remodeling, DNA Methylation, ncRNAs, etc. in Stress-Induced Transcriptional Reprogramming}

The concurrence of various chromatin or epigenetic modifications in plant abiotic/biotic stress responses suggests the importance of the cooperation of these epigenetic regulatory mechanisms in stress-induced transcriptional reprogramming. In particular, the simultaneous appearances of different histone modifications, such as acetylation, methylation, phosphorylation, and ubiquitination in plant stress responses, previously discussed in Section 4 , are known to constitute some epigenetic regulatory networks [2,149]. The bivalent H3K4me3 (active) and H327me3 (repressive) marks at the same stress-responsive genes support the relevance of the interplay of different histone modifications in stress-induced transcriptional reprogramming [24,74]. In addition to the well-established interactions of histone acetylation, methylation, and ubiquitination shown in Table 1, the proportion of rice histone lysine acetylation and acylation, such as lysine butyrylation (Kbu) $(\mathrm{H} 3 \mathrm{~K} 12 / 14 \mathrm{bu}$ and H2BK42/134bu) and crotonylation (Kcr) is dynamically and concertedly regulated in rice under submergence and starvation in order to adapt gene expression [116]. In contrast, the collaborative interactions between different types of epigenetic regulation, such as histone modifications, DNA methylation, chromatin remodeling, and ncRNAs, have been relatively less explored in plant stress responses [34,150], and their importance is only recently being examined in stress-induced transcriptional reprogramming. Therefore, this section discusses three types of epigenetic regulatory interplay in stress-induced transcriptional reprogramming: (1) histone modifications and chromatin remodeling, (2) DNA methylation and ncRNAs, and (3) histone modifications and DNA methylation (Figure 2).

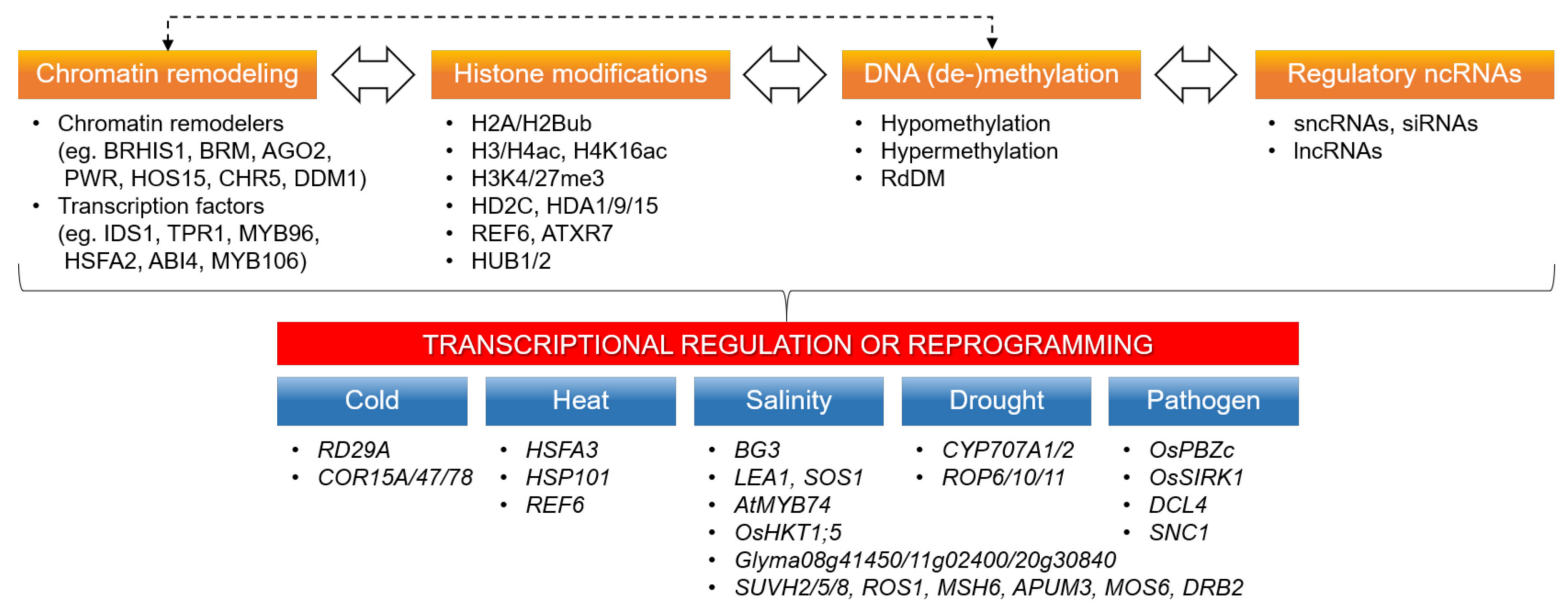

Figure 2. Interplay between histone modifications, chromatin remodeling, DNA (de-)methylation, and ncRNAs in stressinduced transcriptional reprogramming. Cooperative interactions of histone and DNA modifications, histone variants, chromatin remodelers, transcription factors, and ncRNAs in response to cold, heat, salinity, drought, and pathogen infection represent multilayered and multifaceted epigenetic regulation of stress-induced transcriptional reprogramming.

Histone modifications and chromatin remodeling: Various chromatin-modifying proteins have been known to interact with histone modifiers or (in)active chromatin marks in transcriptional regulation or reprogramming [10]. The rice SWI/SNF2 ATPase BRHIS1 constitutes an SWI/SNF2 chromatin remodeling complex and regulates the expression of disease defense-related OsPBZc and OsSIRK1 genes through specific interaction with monoubiquitinated H2A.Xa/H2A.Xb/H2A.3 and H2B.7 variants at those gene loci [134]. The Arabidopsis BRM chromatin remodeler represses the expression of heat-activated HSFA3 and HSP101 genes by removing H4K16ac at their chromatin loci through interaction with the HD2C [55]. In contrast, the Arabidopsis AGO1 binds to the chromatin of stressresponsive genes through interaction with small RNAs and SWI/SNF complexes and promotes their expression in response to cold and phytohormones [52]. Similarly, the rice AGO2 is associated with the enhanced $\mathrm{H} 3 \mathrm{~K} 4 \mathrm{me} 3$ and the reduced $\mathrm{H} 3 \mathrm{~K} 27 \mathrm{me} 3$ levels of 
the $B G 3$ gene to facilitate its expression under salinity stress through chromatin modifications [75]. The PWR proteins also constitute a chromatin-remodeling complex with either HOS15 and HD2C, or HDA9 and ABI4 to repress the cold-responsive RD29A and COR15A/47/78 or the drought-responsive CYP707A1/2 genes, respectively in Arabidopsis $[46,87]$. In addition, histone modifiers and transcription regulators together coordinate chromatin dynamics and gene expression, allowing alternative nucleosome configurations at transcription sites [10-13]. The human transcription factor TFIIH interacts with the histone acetyltransferase KAT2A on chromatin, and this partnership is crucial in the higherorder chromatin dynamics of gene expression [12]. In rice, the transcriptional repressors IDS1 /TPR1 interact with the HDA1 to repress the salt-responsive LEA1 and SOS1 genes through $\mathrm{H} 3$ deacetylation at these gene loci [68]. The Arabidopsis MYB96 transcription factor and deacetylase HDA15 are interdependent in the regulation of ROP suppression through $\mathrm{H} 3 / \mathrm{H} 4$ deacetylation under drought stress [84]. In contrast, the heat-induced HSFA2 transcription factor activates the H3K27me3 demethylase REF6 to regulate its expression through a heritable feedback loop for transgenerational thermomemory in Arabidopsis [56].

DNA methylation and ncRNAs: Small and long ncRNAs (sncRNAs and lncRNAs) play multidimensional roles in such areas as genome stability, chromatin organization, and (post-)transcriptional regulation [38,40]. Gene or locus-specific DNA methylation via the RdDM pathway occurs with the aid of sncRNAs, and there is a relationship between DNA methylation and histone modifications [151,152]. DNA methylation participates in transcriptional repression or activation, regulation of mRNA processing, silencing of transposons and repeats, and chromosome interactions [152]. Transposon-associated DMRs are coupled to the transcript abundance of nearby protein-coding genes in three rice cultivars with different drought and salt tolerances, and sncRNAs are positively correlated with hypermethylated regions, indicating interplay among DNA methylation, gene expression and small RNA abundance in rice abiotic stress response [26]. The reduced accumulation of 24-nt siRNAs in Arabidopsis under salinity stress is associated with transcriptional activation of the heavily methylated but salt-induced AtMYB74 gene via the RdDM pathway [77]. The DICER-LIKE4 (DCL4) gene promoter is hypomethylated in Arabidopsis with Pst infection, resulting in the increased expression of the long DCL4 transcription start site isoform, which functions in a noncanonical siRNA pathway, producing a unique set of 21-nt siRNAs through the RdDM double-stranded RNA synthesis pathway [153]. In addition, the genome-wide DNA methylation patterns in soybean under continuous salinity stress support the combined epigenetic regulation by stress-associated lncRNAs and protein-coding genes [154].

Histone modifications and DNA methylation: The interplay between histone modifications and DNA methylation provides plants with a multifaceted and robust regulatory circuitry for transcriptional reprogramming in response to stress [34,152]. For example, DNA methylation changes as well as various histone modifications, such as H3K4me3, H3K9ac, and $\mathrm{H} 3 \mathrm{~K} 9 \mathrm{me} 2$, are concertedly regulated for transcriptional activation or repression of the salt-responsive genes (Glyma08g41450, Glyma11g02400, Glyma20g30840, SUVH2/5/8, ROS1, MSH6, APUM3, MOS6, and DRB2) in soybean and Arabidopsis [64,65]. The rice transcriptional complex SUVH7-BAG4-MYB106, consisting of a DNA methylation reader, a chaperone regulator, and a transcription factor, activates the OsHKT1;5 expressions during salinity stress [80]. In addition, the expression of the Arabidopsis pathogenesis-related gene $S N C 1$ is cooperatively regulated by the chromatin-remodeling proteins CHR5 and DDM1/SYD for nucleosome occupancy and DNA methylation, along with the histone modifiers HUB1/2 and ATXR7/MOS9 for H2Bub and H3K4me3, respectively, in plant immune responses $[118,130,136]$. However, the concerted interplays between different epigenetic regulators, including chromatin remodeling proteins and histone/DNA modifiers, are still elusive and remain to be investigated. 


\section{Chromatin-Based Transcriptional Reprogramming for Stress Signaling and Memory in Plants}

Plants are sessile organisms that are unavoidably exposed to unfavorable environmental fluctuations over their lifetime and are able to fortify their defenses by adopting a multitude of epigenetic regulatory strategies for stress priming, somatic, intergenerational, and/or transgenerational stress memory $[32,33,155]$. Since stress memory can interfere with full recovery or cause adaptability concerns by sacrificing development and potential yield for a stronger or more rapid future defense response, the recovery process entails a balanced behavior between resetting and memory formation $[156,157]$. During recovery, RNA metabolism, posttranscriptional gene silencing (PTGS), and RdDM play key roles in resetting the epigenome and transcriptome and in altering memory. In addition, stress or defense signaling pathways are epigenetically controlled in plant stress responses through the dynamic engagement of mechanisms, such as histone modifications and DNA methylation $[158,159]$. This section discusses the recent updates in chromatin-based transcriptional reprogramming for stress signaling, priming, and stress memory in plants (Figure 3).

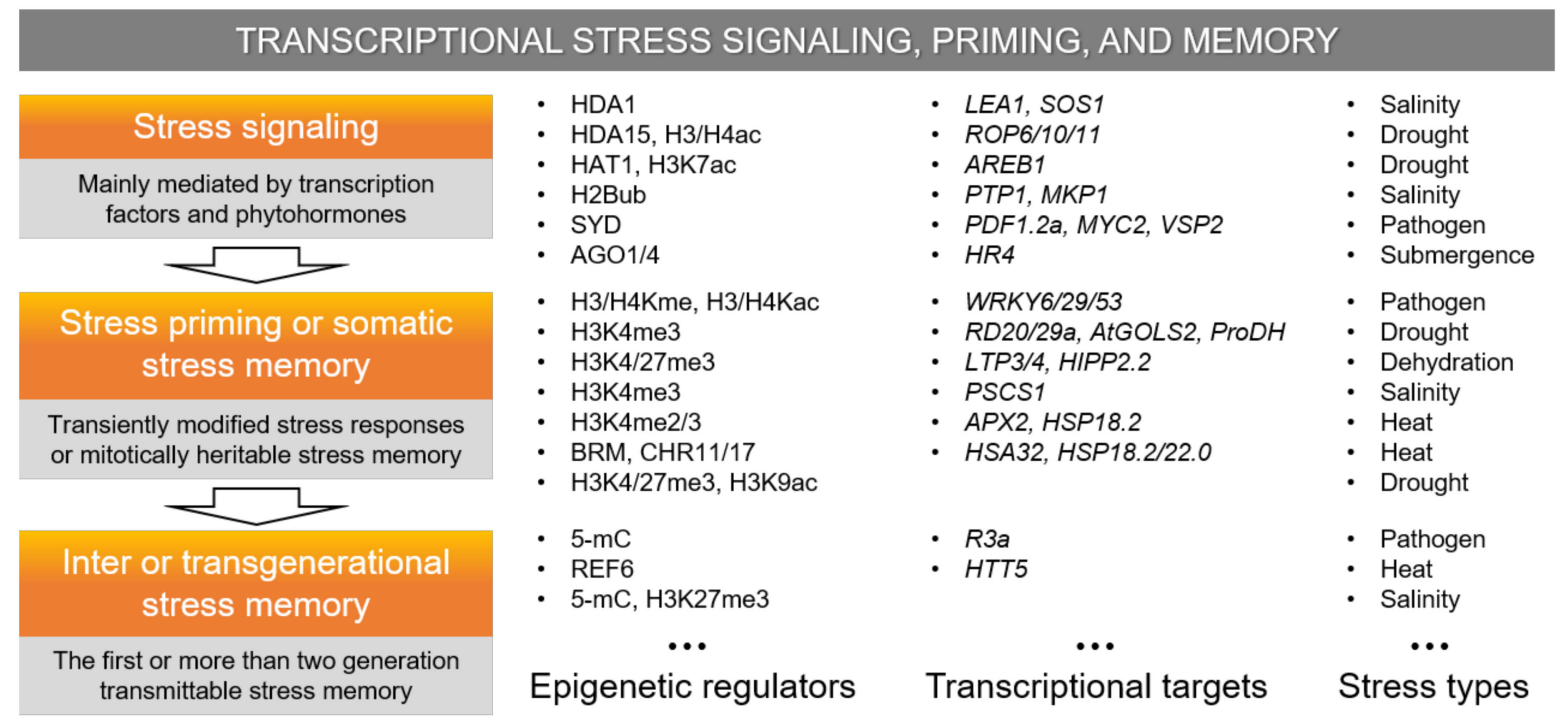

Figure 3. Chromatin-based transcriptional reprogramming for stress signaling, priming, and memory in plant stress response. Pivotal roles of epigenetic regulators or chromatin modifications in plant stress response are somewhat understood in association with transcriptional priming or memory but still remain unclear in heritable transcriptional reprogramming; therefore, they are to be further explored, particularly in relation to inter- or transgenerational stress memory.

Stress signaling: Plant stress signaling pathways are concertedly regulated by multilayers of epigenetic regulators as well as transcription factors and phytohormones activated through the initial stress detection and are associated with the extensive transcriptional reprogramming of stress-related genes [158,159]. The transcription complex of IDS1-TPR1HDA1 regulates salt stress signaling and tolerance in rice by mediating transcriptional repression of abiotic stress-responsive genes, including LEA1 and SOS1, through direct interaction between two transcriptional repressors IDS1/TPR1 and a histone deacetylase HDA1 [68]. The Arabidopsis MYB96 transcription factor recruits the HDA15 to decrease $\mathrm{H} 3 / \mathrm{H} 4$ acetylation at the $\mathrm{ROP}$ genes, which encode negative regulators of ABA signaling and represses these genes under drought stress [84]. The Arabidopsis AREB1, a key positive regulator of drought stress, can be transcriptionally activated by enhancing the H3K27ac at the promoter through the HAT1-fused CRISPR/dCas9 system to improve drought tolerance [83]. Histone H2B (de-)ubiquitination is a dynamic signaling path to chromatin-based control of plant stress responses by facilitating temporary shifts between transcriptionally permissive and repressive chromatin states during drought stress and recovery $[28,29]$. The Arabidopsis H2Bub regulates the expression of PTP1 and MKP1 genes for salinity-induced 
microtubule depolymerization and activates the PTP-MPK3/6 signaling module during salinity stress [76]. In addition, the Arabidopsis SWI/SNF chromatin remodeler SYD positively regulates the JA- and ethylene-responsive PDF1.2a, MYC2, and VSP2 genes through direct interaction with PolII at those gene promoters in response to $B$. cinerea [160]. The Arabidopsis AGO1/4 regulates the expression of $H R 4$ via a noncanonical RdDM pathway in submergence-induced hypoxia signaling [95].

Stress priming or somatic stress memory: Priming can be defined as a transiently modified stress defense response to recurring stress, while somatic stress memory is mitotically heritable and lasts only for the remaining fraction of the lifespan of the organism [33]. RNA metabolism, PTGS, and RdDM play key roles in altering stress memory by resetting the epigenome and transcriptome during recovery [156]. In contrast, multiple layers of chromatin modifications, such as histone modifications, DNA methylation, chromatin remodeling, etc., contribute to plant stress responses, suggesting the role of chromatin dynamics in priming and somatic stress memory [31]. The histone H3/H4 lysine methylation and acetylation changes on the promoters of defense genes WRKY6/29/53 act as transcriptional priming or memory for SAR in Arabidopsis with Psm inoculation [30]. Although the $\mathrm{H} 3 \mathrm{~K} 9 \mathrm{ac}$ and $\mathrm{H} 3 \mathrm{~K} 4 \mathrm{me} 3$ are enriched on the drought- or rehydration-inducible RD20, RD29a, AtGOLS2, and ProDH genes in Arabidopsis by drought stress, the former is rapidly reduced during the recovery by rehydration, but the latter is maintained as an epigenetic mark of stress memory [81]. The enriched H3K4me3 and H3K27me3 marks at the dehydration stress memory genes, such as LTP3, LTP4, and HIPP2.2 during recovery from the initial dehydration stress, are associated with hyper-induction of these genes in Arabidopsis under the recurrent dehydration stress [89]. In addition, the H3K4me3 enhancement contributes to the salinity-induced transcriptional memory of PSCS1 and proline accumulation upon repeated salinity stress in Arabidopsis [73]. The HSFA2-dependent sustained accumulation of $\mathrm{H} 3 \mathrm{~K} 4 \mathrm{me} 2 / 3$ at the promoter of heat stress memory-related genes APX2 and HSP18.2 after acclimatizing heat stress functions as a transcriptional memory for hyper-induction of these genes during recurring heat stress $[57,58]$. The histone modifications $\mathrm{H} 3 \mathrm{~K} 4 \mathrm{me} 3 / \mathrm{H} 3 \mathrm{~K} 9 \mathrm{ac} / \mathrm{H} 3 \mathrm{~K} 27 \mathrm{me} 3$ can be maintained or reset during stress recovery and serve as an epigenetic stress memory of drought-induced transcriptional variations during plant development in maize [104]. In contrast, cold acclimation alters DNA methylation patterns and confers heat tolerance in bok choy [49]. DNA methylation is not sufficient to increase heat-tolerance, but altered DNA methylation contributes to cross-adaptation. In addition, after acclimatizing heat stress in Arabidopsis, chromatin memory through nucleosome remodeling by the interaction of BRM/CHR11/17 chromatin remodelers and FGT1 is responsible for the sustainable induction of the heat-responsive genes HSA32 and HSP18.2/22.0 [63].

Inter- or transgenerational stress memory: Intergenerational memory is detectable only in the first stress-free generation, whereas transgenerational memory transcends at least two stress-free generations, depending on the epigenetic basis [33]. Contrary to the short-term, transient priming and somatic stress memory, the heritable inter- or transgenerational stress memory is challenging to define in the aspect of chromatin-based epigenetic regulation of transcriptional reprogramming and memory [161]. The highly dynamic and transient maternal hyperosmotic stress memory in Arabidopsis depends on the DNA methylation-associated transcriptional changes with an antagonistic relationship between the repressive epigenetic marks hypermethylated DMRs and decreased H3K27me3 marks to transmit the phenotypic plasticity to the immediate offspring [162]. The histone demethylase REF6, transcription factor HSFA2, and trans-acing siRNAs mediate the transcriptional reprogramming of HEAT-INDUCED TAS1 TARGET5 (HTT5) for transgenerational thermomemory in Arabidopsis by constituting a coordinated epigenetic network [56]. In contrast, DNA methylation may be more relevant in the transgenerational defense memory of acclimated or primed plants. Although the Arabidopsis DNA methylome is stable and cannot be correlated with the drought-responsive gene expression under transgenerational drought stress [112], it responded globally to disease in previous generations and contributed to 
the transgenerational acquired resistance [163]. The promoter hypomethylation of the $R 3 a$ resistance gene is required for its enhanced expression in descendants of the primed potato and is associated with intergenerational defense priming to $P$. infestans [144]. In addition, DNA hypomethylation patterns at some pericentromeric regions also contribute to the genome-wide priming of defense-related genes as heritable epigenetic marks, controlling quantitative disease resistance in Arabidopsis [140]. Transgene-induced promoter methylation can be associated with the heritable and transgenerational endogenous gene silencing [164]. Chromatin resetting mechanisms are critical for the prevention of unnecessarily stable transgenerational transmission of stress memory, as well as in balancing between resetting and memory formation during recovery [156,157].

\section{Concluding Remarks and Perspectives}

In this review, the latest studies show that chromatin-based transcriptional regulation is important for both immediate response and future memory in relation to plant stress response; however, multifaceted epigenetic regulation of stress response and memory in plants is still elusive. Different categories of stress memory genes associated with "transcriptional memory", "epigenetic memory," or "delayed memory" suggest distinctive roles of epigenetic signatures in stress-induced transcriptional reprogramming and memory [104]. Differential or cooperative interactions of diverse epigenetic regulators have been poorly studied, and the results or interpretations of these interactions are not cohesive. Increased practical approaches are being attempted for enhancing plant stress tolerance through chromatin-based epigenetic regulation of transcriptional reprogramming and memory. The CRISPR-dCas9 system fused with a histone acetyltransferase and/or a methyltransferase as well as a transcriptional activator can be used to facilitate transcriptional priming through chromatin modifications of specific target genes in plants $[83,165]$. Recently, the importance of chromatin dynamics and epigenetic modifications has become widely recognized in plant stress responses from model plants to crops [21,115,138,166], and some epigenetic regulators, such as histone and DNA modifiers, can be promising targets for increasing stress tolerance and yield in crop plants, including rice, wheat, and barley under abiotic and biotic stresses. In addition, transcriptional reprogramming and memory through chromatin-based epigenetic regulation is the basis of the stress response and memory and is key to improving crop productivity. Therefore, it is necessary to elucidate the interactions of the different epigenetic regulators or modifications and their regulatory mechanisms for transcriptional reprogramming and memory in plant stress response.

Funding: This study was supported by the Ministry of Science and ICT, Republic of Korea.

Conflicts of Interest: The author declares no conflict of interest.

\begin{tabular}{ll}
\multicolumn{2}{l}{ Abbreviations } \\
ABA & Abscisic acid \\
AGO & ARGONAUTE \\
COR & COLD RESPONSIVE \\
DMRs & Differentially methylated regions \\
ERF & ETHYLENE RESPONSE FACTOR \\
GCN5 & GENERAL CONTROL NON-REPRESSED PROTEIN5 \\
H2Bub & Histone H2B monoubiquitination \\
H3K4me3 & Histone 3 lysine 4 trimethylation \\
H3K9ac & Histone 3 lysine 9 acetylation \\
HAT & HISTONE ACETYLTRANSFERASE \\
HDA & HISTONE DEACETYLASE
\end{tabular}




$\begin{array}{ll}\text { HOS15 } & \text { HIGH EXPRESSION OF OSMOTICALLY RESPONSIVE GENE15 } \\ \text { HSF } & \text { HEAT SHOCK TRANSCRIPTION FACTOR } \\ \text { HSP } & \text { HEAT SHOCK PROTEIN } \\ \text { ISWI } & \text { IMITATION SWITCH } \\ \text { Pol } & \text { RNA polymerase } \\ \text { PR1 } & \text { PATHOGENESIS-RELATED GENE1 } \\ \text { PWR } & \text { POWERDRESS } \\ \text { RdDM } & \text { RNA-directed DNA methylation } \\ \text { SA } & \text { Salicylic acid } \\ \text { SAR } & \text { Systemic acquired resistance } \\ \text { SDG } & \text { SET DOMAIN GROUP } \\ \text { siRNAs } & \text { Small-interfering RNAs } \\ \text { sncRNAs or lncRNAs } & \text { Small or long non-coding RNAs } \\ \text { SWI/SNF } & \text { SWITCH/SUCROSE NON-FERMENTABLE }\end{array}$

\section{References}

1. Probst, A.V.; Scheid, O.M. Stress-induced structural changes in plant chromatin. Curr. Opin. Plant Biol. 2015, 27, 8-16. [CrossRef]

2. Kim, J.M.; Sasaki, T.; Ueda, M.; Sako, K.; Seki, M. Chromatin changes in response to drought, salinity, heat, and cold stresses in plants. Front. Plant Sci. 2015, 6, 114. [CrossRef]

3. Lindermayr, C.; Rudolf, E.E.; Durner, J.; Groth, M. Interactions between metabolism and chromatin in plant models. Mol. Metab. 2020, 38, 100951. [CrossRef] [PubMed]

4. Jansen, A.; van der Zande, E.; Meert, W.; Fink, G.R.; Verstrepen, K.J. Distal chromatin structure influences local nucleosome positions and gene expression. Nucleic Acids Res. 2012, 40, 3870-3885. [CrossRef] [PubMed]

5. Bartman, C.R.; Blobel, G.A. Perturbing Chromatin Structure to Understand Mechanisms of Gene Expression. Cold Spring Harb. Symp. Quant. Biol. 2015, 80, 207-212. [CrossRef] [PubMed]

6. Stillman, B. Histone Modifications: Insights into Their Influence on Gene Expression. Cell 2018, 175, 6-9. [CrossRef]

7. To, T.K.; Saze, H.; Kakutani, T. DNA Methylation within Transcribed Regions. Plant Physiol. 2015, 168, 1219-1225. [CrossRef] [PubMed]

8. Madzima, T.F.; Huang, J.; McGinnis, K.M. Chromatin structure and gene expression changes associated with loss of MOP1 activity in Zea mays. Epigenetics 2014, 9, 1047-1059. [CrossRef]

9. Kwon, C.S.; Hibara, K.; Pfluger, J.; Bezhani, S.; Metha, H.; Aida, M.; Tasaka, M.; Wagner, D. A role for chromatin remodeling in regulation of CUC gene expression in the Arabidopsis cotyledon boundary. Development 2006, 133, 3223-3230. [CrossRef] [PubMed]

10. Bornelov, S.; Reynolds, N.; Xenophontos, M.; Gharbi, S.; Johnstone, E.; Floyd, R.; Ralser, M.; Signolet, J.; Loos, R.; Dietmann, S.; et al. The Nucleosome Remodeling and Deacetylation Complex Modulates Chromatin Structure at Sites of Active Transcription to Fine-Tune Gene Expression. Mol. Cell 2018, 71, 56-72.e54. [CrossRef]

11. Brown, C.R.; Mao, C.; Falkovskaia, E.; Jurica, M.S.; Boeger, H. Linking stochastic fluctuations in chromatin structure and gene expression. PLoS Biol. 2013, 11, e1001621. [CrossRef] [PubMed]

12. Sandoz, J.; Nagy, Z.; Catez, P.; Caliskan, G.; Geny, S.; Renaud, J.B.; Concordet, J.P.; Poterszman, A.; Tora, L.; Egly, J.M.; et al. Functional interplay between TFIIH and KAT2A regulates higher-order chromatin structure and class II gene expression. Nat. Commun. 2019, 10, 1288. [CrossRef]

13. Kim, J.H. Chromatin Remodeling and Epigenetic Regulation in Plant DNA Damage Repair. Int. J. Mol. Sci. 2019, 20. [CrossRef]

14. Dong, P.; Tu, X.; Liang, Z.; Kang, B.H.; Zhong, S. Plant and animal chromatin three-dimensional organization: Similar structures but different functions. J. Exp. Bot. 2020, 71, 5119-5128. [CrossRef]

15. Rosa, S.; Shaw, P. Insights into chromatin structure and dynamics in plants. Biology 2013, 2, 1378-1410. [CrossRef]

16. Ojolo, S.P.; Cao, S.; Priyadarshani, S.; Li, W.; Yan, M.; Aslam, M.; Zhao, H.; Qin, Y. Regulation of Plant Growth and Development: A Review from a Chromatin Remodeling Perspective. Front. Plant Sci. 2018, 9, 1232. [CrossRef] [PubMed]

17. Rutowicz, K.; Lirski, M.; Mermaz, B.; Teano, G.; Schubert, J.; Mestiri, I.; Kroten, M.A.; Fabrice, T.N.; Fritz, S.; Grob, S.; et al. Linker histones are fine-scale chromatin architects modulating developmental decisions in Arabidopsis. Genome Biol. 2019, 20, 157. [CrossRef]

18. Luo, M.; Liu, X.; Singh, P.; Cui, Y.; Zimmerli, L.; Wu, K. Chromatin modifications and remodeling in plant abiotic stress responses. Biochim. Biophys. Acta 2012, 1819, 129-136. [CrossRef] [PubMed]

19. Ma, K.W.; Flores, C.; Ma, W. Chromatin configuration as a battlefield in plant-bacteria interactions. Plant Physiol. 2011, 157, 535-543. [CrossRef]

20. Asensi-Fabado, M.A.; Amtmann, A.; Perrella, G. Plant responses to abiotic stress: The chromatin context of transcriptional regulation. Biochim. Biophys. Acta Gene Regul. Mech. 2017, 1860, 106-122. [CrossRef]

21. Kong, L.; Liu, Y.; Wang, X.; Chang, C. Insight into the Role of Epigenetic Processes in Abiotic and Biotic Stress Response in Wheat and Barley. Int. J. Mol. Sci. 2020, 21, 1480. [CrossRef] [PubMed] 
22. Zheng, M.; Liu, X.; Lin, J.; Liu, X.; Wang, Z.; Xin, M.; Yao, Y.; Peng, H.; Zhou, D.X.; Ni, Z.; et al. Histone acetyltransferase GCN5 contributes to cell wall integrity and salt stress tolerance by altering the expression of cellulose synthesis genes. Plant J. 2019, 97, 587-602. [CrossRef]

23. Hu, Z.; Song, N.; Zheng, M.; Liu, X.; Liu, Z.; Xing, J.; Ma, J.; Guo, W.; Yao, Y.; Peng, H.; et al. Histone acetyltransferase GCN5 is essential for heat stress-responsive gene activation and thermotolerance in Arabidopsis. Plant J. 2015, 84, 1178-1191. [CrossRef]

24. Zeng, Z.; Zhang, W.; Marand, A.P.; Zhu, B.; Buell, C.R.; Jiang, J. Cold stress induces enhanced chromatin accessibility and bivalent histone modifications H3K4me3 and H3K27me3 of active genes in potato. Genome Biol. 2019, 20, 123. [CrossRef]

25. Park, J.; Lim, C.J.; Shen, M.; Park, H.J.; Cha, J.Y.; Iniesto, E.; Rubio, V.; Mengiste, T.; Zhu, J.K.; Bressan, R.A.; et al. Epigenetic switch from repressive to permissive chromatin in response to cold stress. Proc. Natl. Acad. Sci. USA 2018, 115, E5400-E5409. [CrossRef]

26. Garg, R.; Chevala, V.N.; Shankar, R.; Jain, M. Divergent DNA methylation patterns associated with gene expression in rice cultivars with contrasting drought and salinity stress response. Sci. Rep. 2015, 5, 14922. [CrossRef] [PubMed]

27. Liu, G.; Xia, Y.; Liu, T.; Dai, S.; Hou, X. The DNA Methylome and Association of Differentially Methylated Regions with Differential Gene Expression during Heat Stress in Brassica rapa. Int. J. Mol. Sci. 2018, 19, 1414. [CrossRef]

28. Bourbousse, C.; Barneche, F. A Dynamic Signaling Path to Chromatin-Level Control of Plant Drought Response. Mol. Plant 2019, 12, 292-294. [CrossRef] [PubMed]

29. Miricescu, A.; Goslin, K.; Graciet, E. Ubiquitylation in plants: Signaling hub for the integration of environmental signals. J. Exp. Bot. 2018, 69, 4511-4527. [CrossRef] [PubMed]

30. Jaskiewicz, M.; Conrath, U.; Peterhansel, C. Chromatin modification acts as a memory for systemic acquired resistance in the plant stress response. EMBO Rep. 2011, 12, 50-55. [CrossRef]

31. Baurle, I.; Trindade, I. Chromatin regulation of somatic abiotic stress memory. J. Exp. Bot. 2020, 71, 5269-5279. [CrossRef]

32. Kinoshita, T.; Seki, M. Epigenetic memory for stress response and adaptation in plants. Plant Cell Physiol. 2014, 55, 1859-1863. [CrossRef]

33. Lamke, J.; Baurle, I. Epigenetic and chromatin-based mechanisms in environmental stress adaptation and stress memory in plants. Genome Biol. 2017, 18, 124. [CrossRef]

34. Pikaard, C.S.; Scheid, O.M. Epigenetic regulation in plants. Cold Spring Harb. Perspect. Biol. 2014, 6, a019315. [CrossRef] [PubMed]

35. Vergara, Z.; Gutierrez, C. Emerging roles of chromatin in the maintenance of genome organization and function in plants. Genome Biol. 2017, 18, 96. [CrossRef]

36. Zhang, Y.; Wendte, J.M.; Ji, L.; Schmitz, R.J. Natural variation in DNA methylation homeostasis and the emergence of epialleles. Proc. Natl. Acad. Sci. USA 2020, 117, 4874-4884. [CrossRef] [PubMed]

37. Raju, S.K.K.; Ritter, E.J.; Niederhuth, C.E. Establishment, maintenance, and biological roles of non-CG methylation in plants. Essays Biochem. 2019, 63, 743-755. [CrossRef]

38. Marchese, F.P.; Raimondi, I.; Huarte, M. The multidimensional mechanisms of long noncoding RNA function. Genome Biol. 2017, 18, 206. [CrossRef]

39. Dona, M.; Scheid, O.M. DNA Damage Repair in the Context of Plant Chromatin. Plant Physiol. 2015, 168, 1206-1218. [CrossRef] [PubMed]

40. Van Wolfswinkel, J.C.; Ketting, R.F. The role of small non-coding RNAs in genome stability and chromatin organization. J. Cell Sci. 2010, 123, 1825-1839. [CrossRef]

41. Dhar, M.K.; Vishal, P.; Sharma, R.; Kaul, S. Epigenetic dynamics: Role of epimarks and underlying machinery in plants exposed to abiotic stress. Int. J. Genomics 2014, 2014, 187146. [CrossRef] [PubMed]

42. Liu, X.; Yang, S.; Zhao, M.; Luo, M.; Yu, C.W.; Chen, C.Y.; Tai, R.; Wu, K. Transcriptional repression by histone deacetylases in plants. Mol. Plant 2014, 7, 764-772. [CrossRef]

43. Banerjee, A.; Wani, S.H.; Roychoudhury, A. Epigenetic Control of Plant Cold Responses. Front. Plant Sci. 2017, 8, 1643. [CrossRef]

44. Song, Y.; Liu, L.; Li, G.; An, L.; Tian, L. Trichostatin A and 5-Aza-2'-Deoxycytidine influence the expression of cold-induced genes in Arabidopsis. Plant Signal. Behav. 2017, 12, e1389828. [CrossRef] [PubMed]

45. Roy, D.; Paul, A.; Roy, A.; Ghosh, R.; Ganguly, P.; Chaudhuri, S. Differential acetylation of histone H3 at the regulatory region of OsDREB1b promoter facilitates chromatin remodelling and transcription activation during cold stress. PLoS ONE 2014, 9, e100343. [CrossRef] [PubMed]

46. Lim, C.J.; Park, J.; Shen, M.; Park, H.J.; Cheong, M.S.; Park, K.S.; Baek, D.; Bae, M.J.; Ali, A.; Jan, M.; et al. The Histone-Modifying Complex PWR/HOS15/HD2C Epigenetically Regulates Cold Tolerance. Plant Physiol. 2020, 184, 1097-1111. [CrossRef] [PubMed]

47. Song, C.; Yang, Y.; Yang, T.; Ba, L.; Zhang, H.; Han, Y.; Xiao, Y.; Shan, W.; Kuang, J.; Chen, J.; et al. MaMYB4 Recruits Histone Deacetylase MaHDA2 and Modulates the Expression of omega-3 Fatty Acid Desaturase Genes during Cold Stress Response in Banana Fruit. Plant Cell Physiol. 2019, 60, 2410-2422. [CrossRef]

48. Miura, K.; Renhu, N.; Suzaki, T. The PHD finger of Arabidopsis SIZ1 recognizes trimethylated histone H3K4 mediating SIZ1 function and abiotic stress response. Commun. Biol. 2020, 3, 23. [CrossRef]

49. Liu, T.; Li, Y.; Duan, W.; Huang, F.; Hou, X. Cold acclimation alters DNA methylation patterns and confers tolerance to heat and increases growth rate in Brassica rapa. J. Exp. Bot. 2017, 68, 1213-1224. [CrossRef]

50. Guo, H.; Wu, T.; Li, S.; He, Q.; Yang, Z.; Zhang, W.; Gan, Y.; Sun, P.; Xiang, G.; Zhang, H.; et al. The Methylation Patterns and Transcriptional Responses to Chilling Stress at the Seedling Stage in Rice. Int. J. Mol. Sci. 2019, 20, 5089. [CrossRef] 
51. Kidokoro, S.; Kim, J.S.; Ishikawa, T.; Suzuki, T.; Shinozaki, K.; Yamaguchi-Shinozaki, K. DREB1A/CBF3 Is Repressed by TransgeneInduced DNA Methylation in the Arabidopsis ice1 -1 Mutant. Plant Cell 2020, 32, 1035-1048. [CrossRef]

52. Liu, C.; Xin, Y.; Xu, L.; Cai, Z.; Xue, Y.; Liu, Y.; Xie, D.; Liu, Y.; Qi, Y. Arabidopsis ARGONAUTE 1 Binds Chromatin to Promote Gene Transcription in Response to Hormones and Stresses. Dev. Cell 2018, 44, 348-361. [CrossRef]

53. Liu, J.; Feng, L.; Li, J.; He, Z. Genetic and epigenetic control of plant heat responses. Front. Plant Sci. 2015, 6, 267. [CrossRef]

54. Weng, M.; Yang, Y.; Feng, H.; Pan, Z.; Shen, W.H.; Zhu, Y.; Dong, A. Histone chaperone ASF1 is involved in gene transcription activation in response to heat stress in Arabidopsis thaliana. Plant Cell Environ. 2014, 37, 2128-2138. [CrossRef] [PubMed]

55. Buszewicz, D.; Archacki, R.; Palusinski, A.; Kotlinski, M.; Fogtman, A.; Iwanicka-Nowicka, R.; Sosnowska, K.; Kucinski, J.; Pupel, P.; Oledzki, J.; et al. HD2C histone deacetylase and a SWI/SNF chromatin remodelling complex interact and both are involved in mediating the heat stress response in Arabidopsis. Plant Cell Environ. 2016, 39, 2108-2122. [CrossRef] [PubMed]

56. Liu, J.; Feng, L.; Gu, X.; Deng, X.; Qiu, Q.; Li, Q.; Zhang, Y.; Wang, M.; Deng, Y.; Wang, E.; et al. An H3K27me3 demethylase-HSFA2 regulatory loop orchestrates transgenerational thermomemory in Arabidopsis. Cell Res. 2019, 29, 379-390. [CrossRef]

57. Lamke, J.; Brzezinka, K.; Altmann, S.; Baurle, I. A hit-and-run heat shock factor governs sustained histone methylation and transcriptional stress memory. EMBO J. 2016, 35, 162-175. [CrossRef] [PubMed]

58. Lamke, J.; Brzezinka, K.; Baurle, I. HSFA2 orchestrates transcriptional dynamics after heat stress in Arabidopsis thaliana. Transcription 2016, 7, 111-114. [CrossRef] [PubMed]

59. Pajoro, A.; Severing, E.; Angenent, G.C.; Immink, R.G.H. Histone H3 lysine 36 methylation affects temperature-induced alternative splicing and flowering in plants. Genome Biol. 2017, 18, 102. [CrossRef] [PubMed]

60. Popova, O.V.; Dinh, H.Q.; Aufsatz, W.; Jonak, C. The RdDM pathway is required for basal heat tolerance in Arabidopsis. Mol. Plant 2013, 6, 396-410. [CrossRef]

61. Naydenov, M.; Baev, V.; Apostolova, E.; Gospodinova, N.; Sablok, G.; Gozmanova, M.; Yahubyan, G. High-temperature effect on genes engaged in DNA methylation and affected by DNA methylation in Arabidopsis. Plant Physiol. Biochem. 2015, 87, 102-108. [CrossRef] [PubMed]

62. Sanchez, D.H.; Paszkowski, J. Heat-induced release of epigenetic silencing reveals the concealed role of an imprinted plant gene. PLoS Genet. 2014, 10, e1004806. [CrossRef]

63. Brzezinka, K.; Altmann, S.; Czesnick, H.; Nicolas, P.; Gorka, M.; Benke, E.; Kabelitz, T.; Jahne, F.; Graf, A.; Kappel, C.; et al. Arabidopsis FORGETTER1 mediates stress-induced chromatin memory through nucleosome remodeling. eLife 2016, 5. [CrossRef]

64. Bilichak, A.; Ilnystkyy, Y.; Hollunder, J.; Kovalchuk, I. The progeny of Arabidopsis thaliana plants exposed to salt exhibit changes in DNA methylation, histone modifications and gene expression. PLoS ONE 2012, 7, e30515. [CrossRef]

65. Song, Y.; Ji, D.; Li, S.; Wang, P.; Li, Q.; Xiang, F. The dynamic changes of DNA methylation and histone modifications of salt responsive transcription factor genes in soybean. PLoS ONE 2012, 7, e41274. [CrossRef] [PubMed]

66. Li, H.; Yan, S.; Zhao, L.; Tan, J.; Zhang, Q.; Gao, F.; Wang, P.; Hou, H.; Li, L. Histone acetylation associated up-regulation of the cell wall related genes is involved in salt stress induced maize root swelling. BMC Plant Biol. 2014, 14, 105. [CrossRef] [PubMed]

67. Mayer, K.S.; Chen, X.; Sanders, D.; Chen, J.; Jiang, J.; Nguyen, P.; Scalf, M.; Smith, L.M.; Zhong, X. HDA9-PWR-HOS15 Is a Core Histone Deacetylase Complex Regulating Transcription and Development. Plant Physiol. 2019, 180, 342-355. [CrossRef]

68. Cheng, X.; Zhang, S.; Tao, W.; Zhang, X.; Liu, J.; Sun, J.; Zhang, H.; Pu, L.; Huang, R.; Chen, T. INDETERMINATE SPIKELET1 Recruits Histone Deacetylase and a Transcriptional Repression Complex to Regulate Rice Salt Tolerance. Plant Physiol. 2018, 178, 824-837. [CrossRef]

69. Ueda, M.; Matsui, A.; Watanabe, S.; Kobayashi, M.; Saito, K.; Tanaka, M.; Ishida, J.; Kusano, M.; Seo, M.; Seki, M. Transcriptome Analysis of the Hierarchical Response of Histone Deacetylase Proteins That Respond in an Antagonistic Manner to Salinity Stress. Front. Plant Sci. 2019, 10, 1323. [CrossRef]

70. Ueda, M.; Matsui, A.; Tanaka, M.; Nakamura, T.; Abe, T.; Sako, K.; Sasaki, T.; Kim, J.M.; Ito, A.; Nishino, N.; et al. The Distinct Roles of Class I and II RPD3-Like Histone Deacetylases in Salinity Stress Response. Plant Physiol. 2017, 175, 1760-1773. [CrossRef]

71. Zhang, Z.; Zhang, S.; Zhang, Y.; Wang, X.; Li, D.; Li, Q.; Yue, M.; Li, Q.; Zhang, Y.E.; Xu, Y.; et al. Arabidopsis floral initiator SKB1 confers high salt tolerance by regulating transcription and pre-mRNA splicing through altering histone H4R3 and small nuclear ribonucleoprotein LSM4 methylation. Plant Cell 2011, 23, 396-411. [CrossRef]

72. Shen, Y.; Conde, E.S.N.; Audonnet, L.; Servet, C.; Wei, W.; Zhou, D.X. Over-expression of histone H3K4 demethylase gene JMJ15 enhances salt tolerance in Arabidopsis. Front. Plant Sci. 2014, 5, 290. [CrossRef] [PubMed]

73. Feng, X.J.; Li, J.R.; Qi, S.L.; Lin, Q.F.; Jin, J.B.; Hua, X.J. Light affects salt stress-induced transcriptional memory of P5CS1 in Arabidopsis. Proc. Natl. Acad. Sci. USA 2016, 113, E8335-E8343. [CrossRef]

74. Han, B.; Xu, W.; Ahmed, N.; Yu, A.; Wang, Z.; Liu, A. Changes and Associations of Genomic Transcription and Histone Methylation with Salt Stress in Castor Bean. Plant. Cell Physiol. 2020, 61, 1120-1133. [CrossRef] [PubMed]

75. Yin, W.; Xiao, Y.; Niu, M.; Meng, W.; Li, L.; Zhang, X.; Liu, D.; Zhang, G.; Qian, Y.; Sun, Z.; et al. ARGONAUTE2 Enhances Grain Length and Salt Tolerance by Activating BIG GRAIN3 to Modulate Cytokinin Distribution in Rice. Plant Cell 2020, 32, $2292-2306$. [CrossRef] [PubMed]

76. Zhou, S.; Chen, Q.; Sun, Y.; Li, Y. Histone H2B monoubiquitination regulates salt stress-induced microtubule depolymerization in Arabidopsis. Plant Cell Environ. 2017, 40, 1512-1530. [CrossRef]

77. Xu, R.; Wang, Y.; Zheng, H.; Lu, W.; Wu, C.; Huang, J.; Yan, K.; Yang, G.; Zheng, C. Salt-induced transcription factor MYB74 is regulated by the RNA-directed DNA methylation pathway in Arabidopsis. J. Exp. Bot. 2015, 66, 5997-6008. [CrossRef] 
78. Kumar, S.; Beena, A.S.; Awana, M.; Singh, A. Salt-Induced Tissue-Specific Cytosine Methylation Downregulates Expression of HKT Genes in Contrasting Wheat (Triticum aestivum L.) Genotypes. DNA Cell Biol. 2017, 36, 283-294. [CrossRef] [PubMed]

79. Yaish, M.W.; Al-Lawati, A.; Al-Harrasi, I.; Patankar, H.V. Genome-wide DNA Methylation analysis in response to salinity in the model plant caliph medic (Medicago truncatula). BMC Genomics 2018, 19, 78. [CrossRef]

80. Wang, J.; Nan, N.; Li, N.; Liu, Y.; Wang, T.J.; Hwang, I.; Liu, B.; Xu, Z.Y. A DNA Methylation Reader-Chaperone RegulatorTranscription Factor Complex Activates OsHKT1;5 Expression during Salinity Stress. Plant Cell 2020, 32, 3535-3558. [CrossRef]

81. Kim, J.M.; To, T.K.; Ishida, J.; Matsui, A.; Kimura, H.; Seki, M. Transition of chromatin status during the process of recovery from drought stress in Arabidopsis thaliana. Plant Cell Physiol. 2012, 53, 847-856. [CrossRef] [PubMed]

82. Li, S.; Lin, Y.J.; Wang, P.; Zhang, B.; Li, M.; Chen, S.; Shi, R.; Tunlaya-Anukit, S.; Liu, X.; Wang, Z.; et al. The AREB1 Transcription Factor Influences Histone Acetylation to Regulate Drought Responses and Tolerance in Populus trichocarpa. Plant Cell 2019, 31, 663-686. [CrossRef]

83. Paixao, J.F.R.; Gillet, F.X.; Ribeiro, T.P.; Bournaud, C.; Lourenco-Tessutti, I.T.; Noriega, D.D.; Melo, B.P.; de Almeida-Engler, J.; Grossi-de-Sa, M.F. Improved drought stress tolerance in Arabidopsis by CRISPR/dCas9 fusion with a Histone AcetylTransferase. Sci. Rep. 2019, 9, 8080. [CrossRef] [PubMed]

84. Lee, H.G.; Seo, P.J. MYB96 recruits the HDA15 protein to suppress negative regulators of ABA signaling in Arabidopsis. Nat. Commun. 2019, 10, 1713. [CrossRef] [PubMed]

85. Zheng, Y.; Ding, Y.; Sun, X.; Xie, S.; Wang, D.; Liu, X.; Su, L.; Wei, W.; Pan, L.; Zhou, D.X. Histone deacetylase HDA9 negatively regulates salt and drought stress responsiveness in Arabidopsis. J. Exp. Bot. 2016, 67, 1703-1713. [CrossRef]

86. Baek, D.; Shin, G.; Kim, M.C.; Shen, M.; Lee, S.Y.; Yun, D.J. Histone Deacetylase HDA9 With ABI4 Contributes to Abscisic Acid Homeostasis in Drought Stress Response. Front. Plant Sci. 2020, 11, 143. [CrossRef]

87. Ali, A.; Yun, D.J. Chromatin remodeling complex HDA9-PWR-ABI4 epigenetically regulates drought stress response in plants. Plant Signal. Behav. 2020, 15, 1803568. [CrossRef]

88. Temel, A.; Janack, B.; Humbeck, K. Drought Stress-Related Physiological Changes and Histone Modifications in Barley Primary Leaves at HSP17 Gene. Agronomy 2017, 7, 43. [CrossRef]

89. Liu, N.; Fromm, M.; Avramova, Z. H3K27me3 and H3K4me3 chromatin environment at super-induced dehydration stress memory genes of Arabidopsis thaliana. Mol. Plant 2014, 7, 502-513. [CrossRef]

90. Huang, S.; Zhang, A.; Jin, J.B.; Zhao, B.; Wang, T.J.; Wu, Y.; Wang, S.; Liu, Y.; Wang, J.; Guo, P.; et al. Arabidopsis histone H3K4 demethylase JMJ17 functions in dehydration stress response. New Phytol. 2019, 223, 1372-1387. [CrossRef] [PubMed]

91. Tsuji, H.; Saika, H.; Tsutsumi, N.; Hirai, A.; Nakazono, M. Dynamic and reversible changes in histone H3-Lys4 methylation and H3 acetylation occurring at submergence-inducible genes in rice. Plant Cell Physiol. 2006, 47, 995-1003. [CrossRef]

92. Li, C.; Liu, D.; Lin, Z.; Guan, B.; Liu, D.; Yang, L.; Deng, X.; Mei, F.; Zhou, Z. Histone acetylation modification affects cell wall degradation and aerenchyma formation in wheat seminal roots under waterlogging. Plant Growth Regul. 2019, 87, 149-163. [CrossRef]

93. Bui, L.T.; Shukla, V.; Giorgi, F.M.; Trivellini, A.; Perata, P.; Licausi, F.; Giuntoli, B. Differential submergence tolerance between juvenile and adult Arabidopsis plants involves the ANAC017 transcription factor. Plant J. 2020, 104, 979-994. [CrossRef] [PubMed]

94. Dossa, K.; Mmadi, M.A.; Zhou, R.; Zhou, Q.; Yang, M.; Cisse, N.; Diouf, D.; Wang, L.; Zhang, X. The contrasting response to drought and waterlogging is underpinned by divergent DNA methylation programs associated with transcript accumulation in sesame. Plant Sci. 2018, 277, 207-217. [CrossRef]

95. Loreti, E.; Betti, F.; Ladera-Carmona, M.J.; Fontana, F.; Novi, G.; Valeri, M.C.; Perata, P. ARGONAUTE1 and ARGONAUTE4 Regulate Gene Expression and Hypoxia Tolerance. Plant Physiol. 2020, 182, 287-300. [CrossRef] [PubMed]

96. Feng, S.J.; Liu, X.S.; Tao, H.; Tan, S.K.; Chu, S.S.; Oono, Y.; Zhang, X.D.; Chen, J.; Yang, Z.M. Variation of DNA methylation patterns associated with gene expression in rice (Oryza sativa) exposed to cadmium. Plant Cell Environ. 2016, 39, 2629-2649. [CrossRef] [PubMed]

97. Mondal, S.; Go, Y.S.; Lee, S.S.; Chung, B.Y.; Kim, J.H. Characterization of histone modifications associated with DNA damage repair genes upon exposure to gamma rays in Arabidopsis seedlings. J. Radiat. Res. 2016, 57, 646-654. [CrossRef]

98. Pedrotti, L.; Weiste, C.; Nagele, T.; Wolf, E.; Lorenzin, F.; Dietrich, K.; Mair, A.; Weckwerth, W.; Teige, M.; Baena-Gonzalez, E.; et al. Snf1-RELATED KINASE1-Controlled C/S1-bZIP Signaling Activates Alternative Mitochondrial Metabolic Pathways to Ensure Plant Survival in Extended Darkness. Plant Cell 2018, 30, 495-509. [CrossRef]

99. Banerjee, A.; Roychoudhury, A. Epigenetic regulation during salinity and drought stress in plants: Histone modifications and DNA methylation. Plant Gene 2017, 11, 199-204. [CrossRef]

100. Wei, F.; Tang, D.; Li, Z.; Kashif, M.H.; Khan, A.; Lu, H.; Jia, R.; Chen, P. Molecular cloning and subcellular localization of six HDACs and their roles in response to salt and drought stress in kenaf (Hibiscus cannabinus L.). Biol. Res. 2019, 52, 20. [CrossRef] [PubMed]

101. Karan, R.; DeLeon, T.; Biradar, H.; Subudhi, P.K. Salt stress induced variation in DNA methylation pattern and its influence on gene expression in contrasting rice genotypes. PLoS ONE 2012, 7, e40203. [CrossRef]

102. Konate, M.; Wilkinson, M.J.; Mayne, B.T.; Pederson, S.M.; Scott, E.S.; Berger, B.; Rodriguez Lopez, C.M. Salt Stress Induces Non-CG Methylation in Coding Regions of Barley Seedlings (Hordeum vulgare). Epigenomes 2018, 2, 12. [CrossRef] 
103. Mousavi, S.; Regni, L.; Bocchini, M.; Mariotti, R.; Cultrera, N.G.M.; Mancuso, S.; Googlani, J.; Chakerolhosseini, M.R.; Guerrero, C.; Albertini, E.; et al. Physiological, epigenetic and genetic regulation in some olive cultivars under salt stress. Sci. Rep. 2019, 9, 1093. [CrossRef]

104. Forestan, C.; Farinati, S.; Zambelli, F.; Pavesi, G.; Rossi, V.; Varotto, S. Epigenetic signatures of stress adaptation and flowering regulation in response to extended drought and recovery in Zea mays. Plant Cell Environ. 2020, 43, 55-75. [CrossRef]

105. Van Dijk, K.; Ding, Y.; Malkaram, S.; Riethoven, J.J.; Liu, R.; Yang, J.; Laczko, P.; Chen, H.; Xia, Y.; Ladunga, I.; et al. Dynamic changes in genome-wide histone H3 lysine 4 methylation patterns in response to dehydration stress in Arabidopsis thaliana. BMC Plant Biol. 2010, 10, 238. [CrossRef]

106. Wang, W.S.; Pan, Y.J.; Zhao, X.Q.; Dwivedi, D.; Zhu, L.H.; Ali, J.; Fu, B.Y.; Li, Z.K. Drought-induced site-specific DNA methylation and its association with drought tolerance in rice (Oryza sativa L.). J. Exp. Bot. 2011, 62, 1951-1960. [CrossRef] [PubMed]

107. Wang, W.; Qin, Q.; Sun, F.; Wang, Y.; Xu, D.; Li, Z.; Fu, B. Genome-Wide Differences in DNA Methylation Changes in Two Contrasting Rice Genotypes in Response to Drought Conditions. Front. Plant Sci. 2016, 7, 1675. [CrossRef]

108. Correia, B.; Valledor, L.; Hancock, R.D.; Jesus, C.; Amaral, J.; Meijon, M.; Pinto, G. Depicting how Eucalyptus globulus survives drought: Involvement of redox and DNA methylation events. Funct. Plant Biol. 2016, 43, 838-850. [CrossRef]

109. Neves, D.M.; Almeida, L.; Santana-Vieira, D.D.S.; Freschi, L.; Ferreira, C.F.; Filho, W.D.S.S.; Costa, M.G.C.; Micheli, F.; Filho, M.A.C.; Gesteira, A.D.S. Recurrent water deficit causes epigenetic and hormonal changes in citrus plants. Sci. Rep. 2017, 7, 13684. [CrossRef]

110. Lu, X.; Wang, X.; Chen, X.; Shu, N.; Wang, J.; Wang, D.; Wang, S.; Fan, W.; Guo, L.; Guo, X.; et al. Single-base resolution methylomes of upland cotton (Gossypium hirsutum L.) reveal epigenome modifications in response to drought stress. BMC Genomics 2017, 18, 297. [CrossRef] [PubMed]

111. Colaneri, A.C.; Jones, A.M. Genome-wide quantitative identification of DNA differentially methylated sites in Arabidopsis seedlings growing at different water potential. PLoS ONE 2013, 8, e59878. [CrossRef]

112. Ganguly, D.R.; Crisp, P.A.; Eichten, S.R.; Pogson, B.J. The Arabidopsis DNA Methylome Is Stable under Transgenerational Drought Stress. Plant Physiol. 2017, 175, 1893-1912. [CrossRef]

113. Fukao, T.; Barrera-Figueroa, B.E.; Juntawong, P.; Pena-Castro, J.M. Submergence and Waterlogging Stress in Plants: A Review Highlighting Research Opportunities and Understudied Aspects. Front. Plant Sci. 2019, 10, 340. [CrossRef] [PubMed]

114. Han, S.K.; Wagner, D. Role of chromatin in water stress responses in plants. J. Exp. Bot. 2014, 65, 2785-2799. [CrossRef] [PubMed]

115. Saraswat, S.; Yadav, A.K.; Sirohi, P.; Singh, N.K. Role of epigenetics in crop improvement: Water and heat stress. J. Plant Biol. 2017, 60, 231-240. [CrossRef]

116. Lu, Y.; Xu, Q.; Liu, Y.; Yu, Y.; Cheng, Z.Y.; Zhao, Y.; Zhou, D.X. Dynamics and functional interplay of histone lysine butyrylation, crotonylation, and acetylation in rice under starvation and submergence. Genome Biol. 2018, 19, 144. [CrossRef]

117. Ding, B.; Wang, G.L. Chromatin versus pathogens: The function of epigenetics in plant immunity. Front. Plant Sci. 2015, 6, 675. [CrossRef] [PubMed]

118. Ramirez-Prado, J.S.; Piquerez, S.J.M.; Bendahmane, A.; Hirt, H.; Raynaud, C.; Benhamed, M. Modify the Histone to Win the Battle: Chromatin Dynamics in Plant-Pathogen Interactions. Front. Plant Sci. 2018, 9, 355. [CrossRef] [PubMed]

119. Zhu, Q.H.; Shan, W.X.; Ayliffe, M.A.; Wang, M.B. Epigenetic Mechanisms: An Emerging Player in Plant-Microbe Interactions. Mol. Plant Microbe Interact. 2016, 29, 187-196. [CrossRef] [PubMed]

120. Hoang, T.V.; Vo, K.T.X.; Hong, W.-J.; Jung, K.-H.; Jeon, J.-S. Defense Response to Pathogens Through Epigenetic Regulation in Rice. J. Plant Biol. 2018, 61, 1-10. [CrossRef]

121. Chen, J.; Clinton, M.; Qi, G.; Wang, D.; Liu, F.; Fu, Z.Q. Reprogramming and remodeling: Transcriptional and epigenetic regulation of salicylic acid-mediated plant defense. J. Exp. Bot. 2020, 71, 5256-5268. [CrossRef] [PubMed]

122. Meile, L.; Peter, J.; Puccetti, G.; Alassimone, J.; McDonald, B.A.; Sanchez-Vallet, A. Chromatin Dynamics Contribute to the Spatiotemporal Expression Pattern of Virulence Genes in a Fungal Plant Pathogen. mBio 2020, 11. [CrossRef]

123. Defraia, C.T.; Wang, Y.; Yao, J.; Mou, Z. Elongator subunit 3 positively regulates plant immunity through its histone acetyltransferase and radical S-adenosylmethionine domains. BMC Plant Biol. 2013, 13, 102. [CrossRef] [PubMed]

124. Kong, L.; Qiu, X.; Kang, J.; Wang, Y.; Chen, H.; Huang, J.; Qiu, M.; Zhao, Y.; Kong, G.; Ma, Z.; et al. A Phytophthora Effector Manipulates Host Histone Acetylation and Reprograms Defense Gene Expression to Promote Infection. Curr. Biol. 2017, 27, 981-991. [CrossRef]

125. Mengel, A.; Ageeva, A.; Georgii, E.; Bernhardt, J.; Wu, K.; Durner, J.; Lindermayr, C. Nitric Oxide Modulates Histone Acetylation at Stress Genes by Inhibition of Histone Deacetylases. Plant Physiol. 2017, 173, 1434-1452. [CrossRef]

126. Walley, J.W.; Shen, Z.; McReynolds, M.R.; Schmelz, E.A.; Briggs, S.P. Fungal-induced protein hyperacetylation in maize identified by acetylome profiling. Proc. Natl. Acad. Sci. USA 2018, 115, 210-215. [CrossRef]

127. Latrasse, D.; Jegu, T.; Li, H.; de Zelicourt, A.; Raynaud, C.; Legras, S.; Gust, A.; Samajova, O.; Veluchamy, A.; Rayapuram, N.; et al. MAPK-triggered chromatin reprogramming by histone deacetylase in plant innate immunity. Genome Biol. 2017, 18, 131. [CrossRef] [PubMed]

128. Wang, Y.; Hu, Q.; Wu, Z.; Wang, H.; Han, S.; Jin, Y.; Zhou, J.; Zhang, Z.; Jiang, J.; Shen, Y.; et al. HISTONE DEACETYLASE 6 represses pathogen defence responses in Arabidopsis thaliana. Plant Cell Environ. 2017, 40, 2972-2986. [CrossRef]

129. Lee, S.; Fu, F.; Xu, S.; Lee, S.Y.; Yun, D.J.; Mengiste, T. Global Regulation of Plant Immunity by Histone Lysine Methyl Transferases. Plant Cell 2016, 28, 1640-1661. [CrossRef] [PubMed] 
130. Xia, S.; Cheng, Y.T.; Huang, S.; Win, J.; Soards, A.; Jinn, T.L.; Jones, J.D.; Kamoun, S.; Chen, S.; Zhang, Y.; et al. Regulation of transcription of nucleotide-binding leucine-rich repeat-encoding genes SNC1 and RPP4 via H3K4 trimethylation. Plant Physiol. 2013, 162, 1694-1705. [CrossRef] [PubMed]

131. Hou, Y.; Wang, L.; Wang, L.; Liu, L.; Li, L.; Sun, L.; Rao, Q.; Zhang, J.; Huang, S. JMJ704 positively regulates rice defense response against Xanthomonas oryzae pv. oryzae infection via reducing $\mathrm{H} 3 \mathrm{~K} 4 \mathrm{me} 2 / 3$ associated with negative disease resistance regulators. BMC Plant Biol. 2015, 15, 286. [CrossRef]

132. Dutta, A.; Choudhary, P.; Caruana, J.; Raina, R. JMJ27, an Arabidopsis H3K9 histone demethylase, modulates defense against Pseudomonas syringae and flowering time. Plant J. 2017, 91, 1015-1028. [CrossRef] [PubMed]

133. Chan, C.; Zimmerli, L. The Histone Demethylase IBM1 Positively Regulates Arabidopsis Immunity by Control of Defense Gene Expression. Front. Plant Sci. 2019, 10, 1587. [CrossRef]

134. Li, X.; Jiang, Y.; Ji, Z.; Liu, Y.; Zhang, Q. BRHIS1 suppresses rice innate immunity through binding to monoubiquitinated H2A and H2B variants. EMBO Rep. 2015, 16, 1192-1202. [CrossRef] [PubMed]

135. Gomez-Zambrano, A.; Merini, W.; Calonje, M. The repressive role of Arabidopsis H2A.Z in transcriptional regulation depends on AtBMI1 activity. Nat. Commun. 2019, 10, 2828. [CrossRef] [PubMed]

136. Zou, B.; Sun, Q.; Zhang, W.; Ding, Y.; Yang, D.L.; Shi, Z.; Hua, J. The Arabidopsis Chromatin-Remodeling Factor CHR5 Regulates Plant Immune Responses and Nucleosome Occupancy. Plant Cell Physiol. 2017, 58, 2202-2216. [CrossRef] [PubMed]

137. He, C.; Zhang, Z.; Li, B.; Tian, S. The Pattern and Function of DNA Methylation in Fungal Plant Pathogens. Microorganisms 2020, 8. [CrossRef] [PubMed]

138. Tirnaz, S.; Batley, J. DNA Methylation: Toward Crop Disease Resistance Improvement. Trends Plant Sci. 2019, 24, 1137-1150. [CrossRef]

139. Dowen, R.H.; Pelizzola, M.; Schmitz, R.J.; Lister, R.; Dowen, J.M.; Nery, J.R.; Dixon, J.E.; Ecker, J.R. Widespread dynamic DNA methylation in response to biotic stress. Proc. Natl. Acad. Sci. USA 2012, 109, E2183-E2191. [CrossRef]

140. Furci, L.; Jain, R.; Stassen, J.; Berkowitz, O.; Whelan, J.; Roquis, D.; Baillet, V.; Colot, V.; Johannes, F.; Ton, J. Identification and characterisation of hypomethylated DNA loci controlling quantitative resistance in Arabidopsis. eLife 2019, 8. [CrossRef]

141. Sanchez, A.L.; Stassen, J.H.; Furci, L.; Smith, L.M.; Ton, J. The role of DNA (de)methylation in immune responsiveness of Arabidopsis. Plant J. 2016, 88, 361-374. [CrossRef]

142. Sun, Y.; Fan, M.; He, Y. DNA Methylation Analysis of the Citrullus lanatus Response to Cucumber Green Mottle Mosaic Virus Infection by Whole-Genome Bisulfite Sequencing. Genes 2019, 10, 344. [CrossRef]

143. Wang, Y.; An, C.; Zhang, X.; Yao, J.; Zhang, Y.; Sun, Y.; Yu, F.; Amador, D.M.; Mou, Z. The Arabidopsis elongator complex subunit2 epigenetically regulates plant immune responses. Plant Cell 2013, 25, 762-776. [CrossRef]

144. Kuznicki, D.; Meller, B.; Arasimowicz-Jelonek, M.; Braszewska-Zalewska, A.; Drozda, A.; Floryszak-Wieczorek, J. BABA-Induced DNA Methylome Adjustment to Intergenerational Defense Priming in Potato to Phytophthora infestans. Front. Plant Sci. 2019, 10, 650. [CrossRef]

145. Deng, Y.; Zhai, K.; Xie, Z.; Yang, D.; Zhu, X.; Liu, J.; Wang, X.; Qin, P.; Yang, Y.; Zhang, G.; et al. Epigenetic regulation of antagonistic receptors confers rice blast resistance with yield balance. Science 2017, 355, 962-965. [CrossRef] [PubMed]

146. Richard, M.M.S.; Gratias, A.; Thareau, V.; Kim, K.D.; Balzergue, S.; Joets, J.; Jackson, S.A.; Geffroy, V. Genomic and epigenomic immunity in common bean: The unusual features of NB-LRR gene family. DNA Res. 2018, 25, 161-172. [CrossRef] [PubMed]

147. Geng, S.; Kong, X.; Song, G.; Jia, M.; Guan, J.; Wang, F.; Qin, Z.; Wu, L.; Lan, X.; Li, A.; et al. DNA methylation dynamics during the interaction of wheat progenitor Aegilops tauschii with the obligate biotrophic fungus Blumeria graminis f. sp tritici. New Phytol. 2019, 221, 1023-1035. [CrossRef]

148. Gao, S.; Ma, W.; Lyu, X.; Cao, X.; Yao, Y. Melatonin may increase disease resistance and flavonoid biosynthesis through effects on DNA methylation and gene expression in grape berries. BMC Plant Biol. 2020, 20, 231. [CrossRef] [PubMed]

149. Ueda, M.; Seki, M. Histone Modifications Form Epigenetic Regulatory Networks to Regulate Abiotic Stress Response. Plant Physiol. 2020, 182, 15-26. [CrossRef]

150. Santos, A.P.; Ferreira, L.J.; Oliveira, M.M. Concerted Flexibility of Chromatin Structure, Methylome, and Histone Modifications along with Plant Stress Responses. Biology 2017, 6, 3. [CrossRef]

151. Saze, H.; Tsugane, K.; Kanno, T.; Nishimura, T. DNA methylation in plants: Relationship to small RNAs and histone modifications, and functions in transposon inactivation. Plant Cell Physiol. 2012, 53, 766-784. [CrossRef]

152. Zhang, H.; Lang, Z.; Zhu, J.K. Dynamics and function of DNA methylation in plants. Nat. Rev. Mol. Cell Biol. 2018, 19, 489-506. [CrossRef] [PubMed]

153. Pumplin, N.; Sarazin, A.; Jullien, P.E.; Bologna, N.G.; Oberlin, S.; Voinnet, O. DNA Methylation Influences the Expression of DICER-LIKE4 Isoforms, Which Encode Proteins of Alternative Localization and Function. Plant Cell 2016, 28, 2786-2804. [CrossRef] [PubMed]

154. Chen, R.; Li, M.; Zhang, H.; Duan, L.; Sun, X.; Jiang, Q.; Zhang, H.; Hu, Z. Continuous salt stress-induced long non-coding RNAs and DNA methylation patterns in soybean roots. BMC Genomics 2019, 20, 730. [CrossRef] [PubMed]

155. Holeski, L.M.; Jander, G.; Agrawal, A.A. Transgenerational defense induction and epigenetic inheritance in plants. Trends Ecol. Evol. 2012, 27, 618-626. [CrossRef] [PubMed]

156. Crisp, P.A.; Ganguly, D.; Eichten, S.R.; Borevitz, J.O.; Pogson, B.J. Reconsidering plant memory: Intersections between stress recovery, RNA turnover, and epigenetics. Sci. Adv. 2016, 2, e1501340. [CrossRef] 
157. Iwasaki, M. Chromatin resetting mechanisms preventing transgenerational inheritance of epigenetic states. Front. Plant Sci. 2015, 6, 380. [CrossRef]

158. Espinas, N.A.; Saze, H.; Saijo, Y. Epigenetic Control of Defense Signaling and Priming in Plants. Front. Plant Sci. 2016, 7, 1201. [CrossRef]

159. Ramirez-Prado, J.S.; Abulfaraj, A.A.; Rayapuram, N.; Benhamed, M.; Hirt, H. Plant Immunity: From Signaling to Epigenetic Control of Defense. Trends Plant Sci. 2018, 23, 833-844. [CrossRef]

160. Walley, J.W.; Rowe, H.C.; Xiao, Y.; Chehab, E.W.; Kliebenstein, D.J.; Wagner, D.; Dehesh, K. The chromatin remodeler SPLAYED regulates specific stress signaling pathways. PLoS Pathog. 2008, 4, e1000237. [CrossRef]

161. Pecinka, A.; Scheid, O.M. Stress-induced chromatin changes: A critical view on their heritability. Plant Cell Physiol. 2012, 53, 801-808. [CrossRef] [PubMed]

162. Wibowo, A.; Becker, C.; Marconi, G.; Durr, J.; Price, J.; Hagmann, J.; Papareddy, R.; Putra, H.; Kageyama, J.; Becker, J.; et al. Hyperosmotic stress memory in Arabidopsis is mediated by distinct epigenetically labile sites in the genome and is restricted in the male germline by DNA glycosylase activity. eLife 2016, 5. [CrossRef] [PubMed]

163. Stassen, J.H.M.; Lopez, A.; Jain, R.; Pascual-Pardo, D.; Luna, E.; Smith, L.M.; Ton, J. The relationship between transgenerational acquired resistance and global DNA methylation in Arabidopsis. Sci. Rep. 2018, 8, 14761. [CrossRef]

164. Kim, J.S.; Kidokoro, S.; Shinozaki, K.; Yamaguchi-Shinozaki, K. DNA demethylase ROS1 prevents inheritable DREB1A/CBF3 repression by transgene-induced promoter methylation in the Arabidopsis ice1-1 mutant. Plant Mol. Biol. 2020. [CrossRef] [PubMed]

165. Lee, J.E.; Neumann, M.; Duro, D.I.; Schmid, M. CRISPR-based tools for targeted transcriptional and epigenetic regulation in plants. PLoS ONE 2019, 14, e0222778. [CrossRef] [PubMed]

166. Thiebaut, F.; Hemerly, A.S.; Ferreira, P.C.G. A Role for Epigenetic Regulation in the Adaptation and Stress Responses of Non-model Plants. Front. Plant Sci. 2019, 10, 246. [CrossRef] 